\title{
ЖАНУАР АСЫҚТАРЫНЫН АРХЕОЗООЛОГИЯЛЫҚ ЗЕРТТЕЛУІ (Бәбіш мола қаласының материалдары бойынша)
}

\author{
(C) 2019 ж. М.С. Шагирбаев, Ж.Р. Утубаев
}

Мақала Бәбіш-мола қаласынан табылған жануар асықтарының археозоологиялық зерттелу мәселесіне арналады. Ескерткішке жүргізілген қазба жұмыстары барысында 80-нен астам жануар асықтары табылған. Археозоологиялық талдау негізінде, асықтардың қуысмүйізділер (Bovidae) тұқымдасына жататын ақбөкен (Saiga tatarica) және қарақұйрық (Gazella subgutturosa), сонымен қатар қой (Ovis aries) және ешкіге (Capra) тиесілі екендігі белгілі болды. Морфологиялық және морфометриялық зерттеулер барысында жануар асықтарының өлшемдеріндегі ауытқушылық диапазондары (Lim), ортақ квадраттық мөлшері (M), орташа квадраттық ауытқу мөлшері (o) және ортақ арифметикалық қателіктері анықталды. Остеометриялық зерттеу нәтижелері негізінде, Бәбіш моладан табылған асықтарға басқа аймақтардағы жануар асықтарының өлшемдерімен өзара салыстырмалы талдау жасалды. Ақбөкен асықтарының плантарлы бетіне сызылған әртүрлі өрнектердің сипаттамасы жасалынып, биометриялық белгілердің вариациялық қатары шығарылды. Мақалада асықтардың жан-жақты өлшемдері көрсетілген 12 кесте берілген. Археологиялық зерттеулер барысында Қазақстанның әртүрлі аймақтарынан кездескен жануар асықтарын мысалға ала отырып, ондағы асық ойындары, ғұрыптық жосындарға қатысты тұжырымдарға талдау жасалады.

Түйін сөздер: археология, Жаңадария, Бәбіш-мола, цитадель, «Үлкен үй», жануар асықтары, ақбөкен, қарақұйрық, археозоология, асық ойыны, ғұрып, жерлеу орны, морфометриялық талдау, трасология

Kipicne

Ежелгі және ортағасырлық қоныстар мен қалаларға археологиялық қазба жүргізу барысында ең жиі кездесетін материалдардың бірі - жануар сүйектері. Өкінішке орай отандық археологияда жануар сүйектерін жеке-дара талдап, зерттеу нәтижелерінғылымиайналымғаенгізу мәселесі өз деңгейінде емес екендігі белгілі. Бұл мәселе өз кезегінде сүйек материалдарды салыстырмалы талдау кезінде көп қиындықтар туғызады.
Әрине жекелеген ескерткіштерді зерттеу нәтижелері бойынша жарияланып жатқан еңбектерді жоққа шығара алмаймыз. Дегенмен палеозоологиялық зерттеу нәтижелері көп жағдайда абстракты түрде, жануарлардың саны мен сүйек материалдардың сандық және сапалық жағдайына тоқталумен шектеліп қалады. Бұл келеңсіздің басты себебі елімізде арнайы палеозоолог (археозоолог) мамандардың жетіспеуімен және салыстырмалы материалдар базасының әлсіз болу- 
ымен байланысты. Мақаламыздың негізгі мақсаты жануар асықтарына жүргізілген археозоологиялық зерттеу нәтижелерін ғылыми айналымға енгізу. Төмендегі остеометриялық зерттеу нәтижелері алдағы зерттеулерде нақты салыстырмалы материал болумен қатар, отандық археологиядағы жануар асықтары, оның ішінде ақбөкен асықтарының морфологиялық құрамына қатысты мәліметтер базасын толықтырады деп сенеміз.

\section{Ескерткіш тураль жалпь мәлімет}

Бәбіш мола қаласы Қызылорда облысы, Қармақшы ауданы, Т. Көмекбаев ауылынан оңтүстікке қарай 47 шақырым жерде, Сырдарияның көне арнасы Жаңадарияның оң жағалауында орналасқан. Ескерткішті 19571960 жылдары Хорезм археологиялық-этнографиялық экспедициясы зерттеген [Толстов и др., 1960, с. 2340]. 2004 жылдан бері Ә.Х. Марғұлан атындағы Археология институтытына қарасты Шірік Рабат археологиялық экспедициясы қайта барлау жүргізіп, археологиялық зерттеу жұмыстарын жүргізіп келеді [Курманкулов, Утубаев, 2019].

Бәбіш-мола айнала пахсадан жасалған ірге тастың үстіне қам кірпіштен қаланған бекініс қабырғасы бар (қалыңдығы 5,3 м), ірі қала болып табылады. Бекініс қабырғасының бойында қорғаныс жартылай дөңгелек пішінді мұнара іздері сақталған. Қорғаныс қабырғасының сыртқы бетіндегі жер бедерінен құрылыс іздері анық байқалады. Ескерткіштің оңтүстік-батыс бөлігінде қам кірпіштен қаланған жеке құрылыс қалдығы және қатар орналасқан бірнеше каркас-бағаналы үй-жай құрылысы анықталған.
Қаланың солтүстік бөлігінде көлемі $100 \times 100$ м болатын шаршы пішінді цитадель орналасқан. Цитадельдің бұрыштары әлемнің төрт тарабымен бағыттас және айнала пахсадан салынған қабырғамен қоршалған. Цитадельдің бұрышында және шығыс қабырғасының орталық бөлігінде жартылай дөңгелек пішінді мұнара анық көрінеді. Қабырға және мұнараларда қабырға етегінен есептегенде 1,15 м биіктікте атыс ойықтарына арналған тесіктер орналасқан. Атыс ойықтарының биіктігі 40 см. Цитадельге кіретін қақпа оңтүстік қабырға бөлігінде, екі қапталдан жартылай дөңгелек пішінді ipi мұнара арасында орналасқан. Әрі сыртынан «донжон» атауымен белгілі ipi мұнарамен $(30 \times 30$ м) қосымша қорғаныс ұйымдастырылған. Бұл мұнара қабырғасының бүгінде 4-5 м биіктігі сақталған. Донжонның ішінен бірінші қабатқа тән күмбез тәрізді бөлмесі анықталды (сур. 1).

\section{Цитадельдің}

ортасында көлемі 44×44 м болатын шаршы пішінді монументальды құрылыс «Үлкен үй» яғни сарай орналасқан. Құрылыстың сыртқы қабырғасы пахсалы іргетастың үстіне қаланған шикі кірпіштен тұрғызылған. Қабырға бойында атыс ойықтары бар. Ғимараттың бұрыштары ішінде ешқандай құрылыс кешені жоқ мұнаралармен қоршалған (сур. 2).

2018 жылдың 15 тамызында Бәбіш Мола 1 қаласындағы цитаделдің орталық бөлігіндегі ғимаратқа қазба жұмыстары басталды [Курманкулов, Утубаев, 2019]. Қазба негізінен дәстүрлі түрде Жаңадария аңғарындағы «облыс билеушісінің сарайы» саналатын монументальды ғимараттың солтүстік-батыс бөлігіне салынды. 
Шагирбаев М.С., Утубаев Ж.Р. Жануар асықтарының археозоологиялық зерттелуі

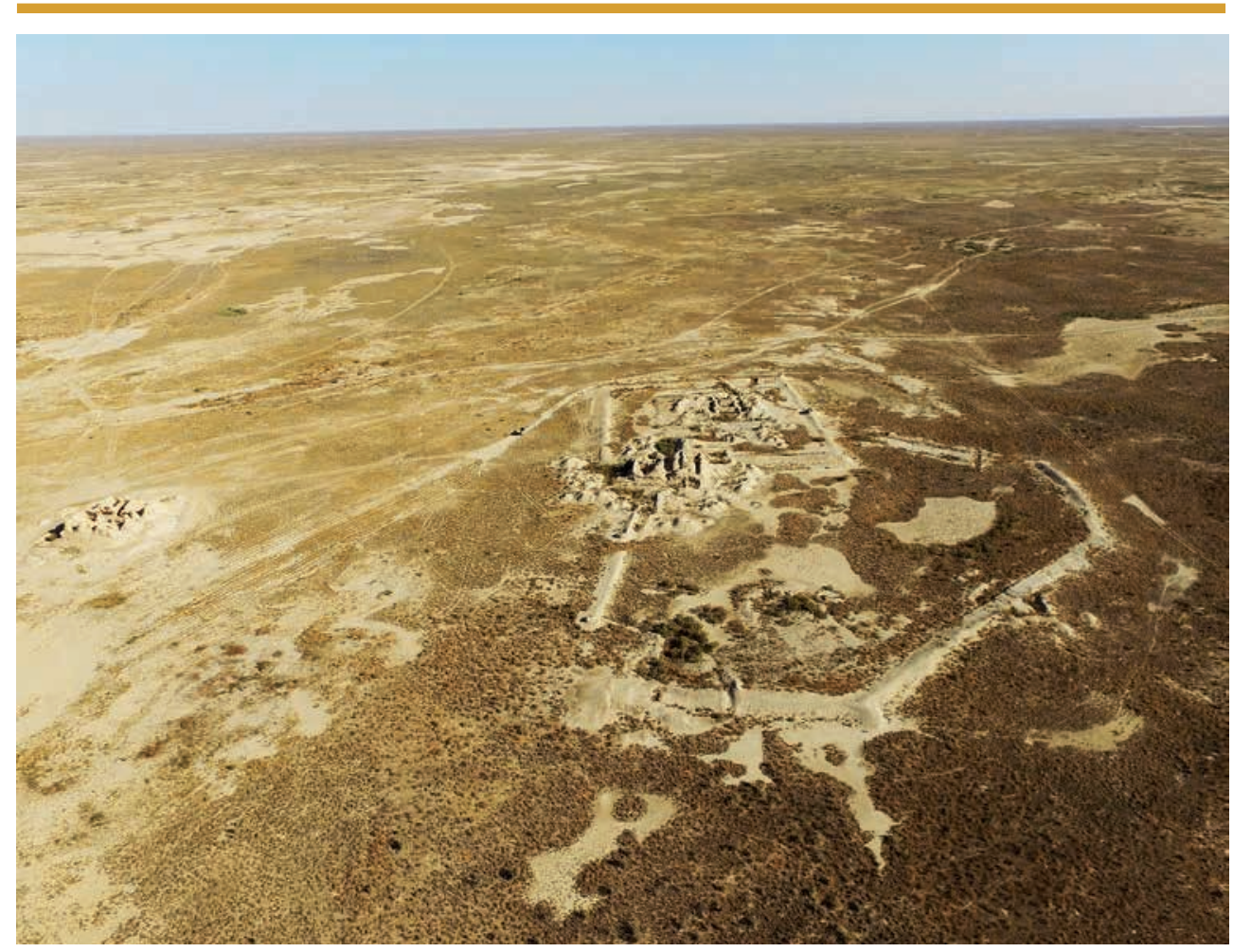

Сур. 1. Бәбіш мола. Ж.Р. Утубаевтың фотосы

Fig. 1. Babish mola. Photo by Zh.R. Utubayev

Қазбаның жалпы көлемі $128 \mathbf{m}^{2}$. Кейбір бөліктеріндегі қазба тереңдігі құрылымына қарай 2 м асады. Қазба барысында ғимарат ішінде айнала орналасқан дәліздің кейбір бөліктері, солтүстік-батыс бұрышындағы жолмен жалғасатын екі бөлменің кейбір бөліктері ашылды. Барлық қабырғадағы кірпіштердің көлемі үлкен, негізгі өлшемдері 42×42×12$13 \mathrm{~cm} ; 39 \times 40 \times 12 \mathrm{~cm} ; 38 \times 39 \times 12 \mathrm{~cm}$; $43 \times 44 \times 12-13$ см құрайды. Айта кететін жағдай, құрылысқа шаршы пішінді кірпіштермен қатар тікбұрышты кірпіштер де қаланған. Олардың негізгі өлшемдері $47 \times 38 \times 13 \quad$ см; $45 \times 35 \times 12$ см; 49×37×12 смаралығында ауытқиды. Кірпіштердің қалануы тұрақты, қаланды қатары бір-біріне жалғаспалы түрде орналасқан, сонымен қатар жоғарғы қатардағы кірпіштердің жылжу амплитудасы төменгі кірпіш қатарына қарағанда жарты кірпіш көлеміне сәйкес. Қазба барысындағы стратиграфиялық мәліметтер ғимаратта екі құрылыс кезеңі бар екендігін көрсетіп отыр. Негізгі құрылыс кезеңі яғни ерте кезеңі және ішінара өмір сүрген құрылыс кезеңі. Қазбаның батыс және солтүстік-батыс бөлігіндегі стратиграфиялық жағдай ғимараттың екі құрылыс кезеңі арасында біршама уақыт үзілісте болғанын айғақтайды. Мұны кейбір бөлмелердің қабырғаларындағы бұзылған белгілерден анық көруге болады.

Екінші кезең (ฉимараттың өмір сүруінің соңды этапы). «Үлкен үйдің» кейбір бөліктеріндегі соңғы кезеңге тән тіршілік белгілері қазбаның батыс бөлігінен анықталды. Бұл кезеңдегі құрылыс деңгейі айнала дәлізден анықталды. Солтүстік бөлікте ре- 


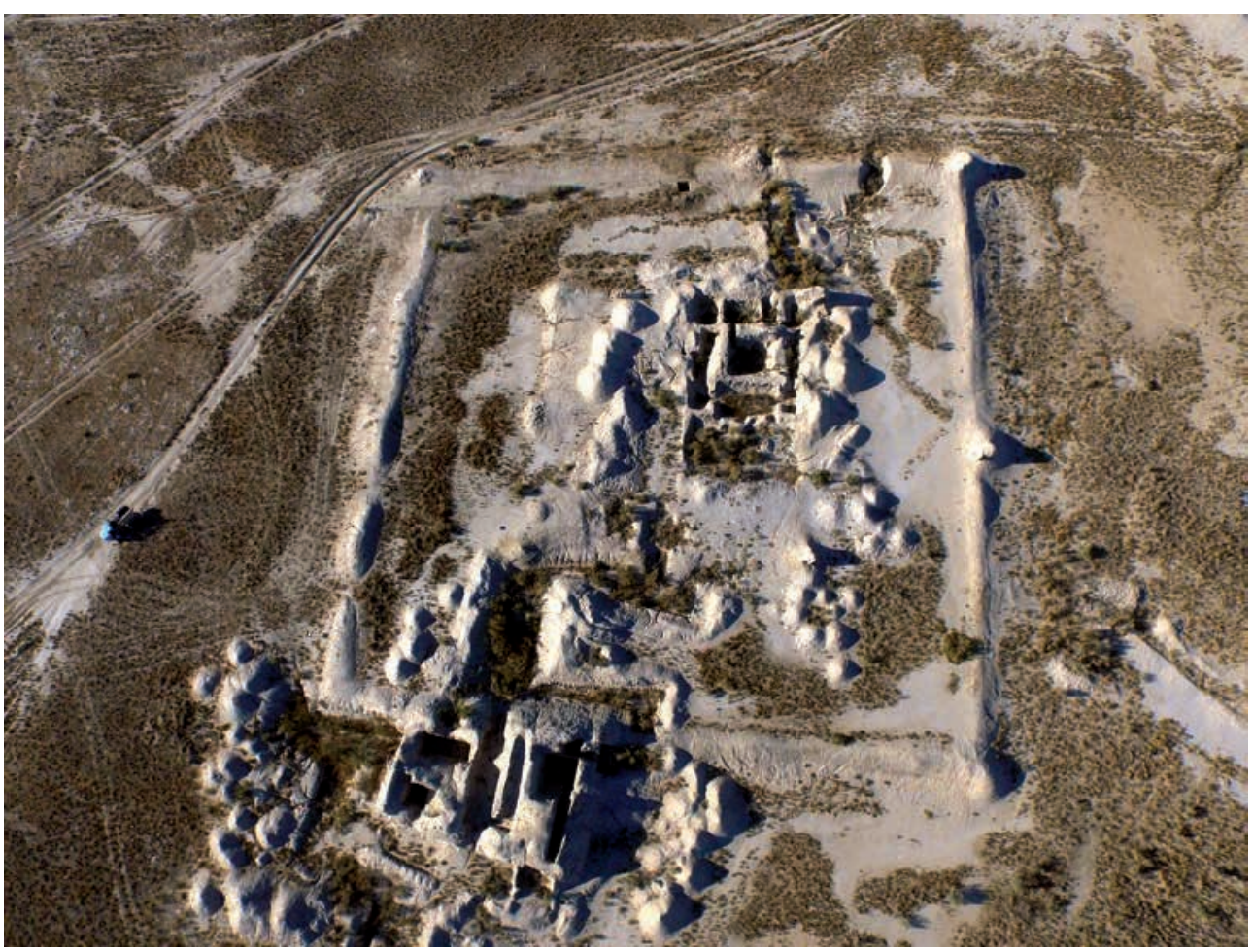

Сур. 2. Бәбіш мола қуаласының изитаделі. «Үлкен үй». Ж.Р. Утубаевтың фотосы

Fig. 2. Citadel of Babish mola. «Big house». Photo by Zh.R. Utubayev

пер нүктесінен 80-84 см, солтүстікбатыс бөлікте репер нүктесінен 6670 см тереңдікке жетеді. Бұл шамасы ғимараттың тіршілік етуінің соңғы кезеңіндегі кірпіш құландыларының жоғарғы деңгейі болуы мүмкін. Айнала дәліздің солтүстік-батыс бұрышында репер нүктесінен 72 см деңгейдегі екінші құрылыс кезеңінен жерлеу орны ашылды. Ондағы тазаланған сүйектер, оның ішінде бас сүйек, түтікшелі ұзын сүйектер және жақ сүйектері біршама шеткері орналасқан. Ескерткіштің кейінгі өмір сүру деңгейімен байланысты, дәліздің батыс қабырғасынан 2 м қашықта орналасқан ошақ орны анықталды. Ошақтың диаметрі 7075 см, аса терең емес және ішінде күл толтырылған. Қызыл және қызғылтсары түсті ошақтың түбі репер нүктесінен 83-84 белгіде анықталды.
Ошақтың жанынан диаметрі 1 м болатын, ішінде күл аралас ағаш көмірлері бар шұңқыр анықталды. Ошақтан шамамен оңтүстікке қарай 40 см жерден, ескерткіштің өмір сүруінің кейінгі кезеңіне тән деңгейден сопақ пішінді, диаметрі 50 см, тереңдігі 40-45 см болатын шұңқыр тазаланды. Шұңқыр негізінен борпылдақ құм топырақ және арасында аздаған мөлшерде күл араласқан кірпіш сынықтарымен толтырылған. Осы шұңқырдан 60-тан астам уақ мал тұқымдасына тиесілі асықтар және жанынан тағы да бөлек орналасқан уақ мал тұқымдасына тән 20-дан астам асықтар анықталды (сур. 3-4).

Әдіснама және зерттеу дәістерi

Зерттеу жұмысының негізгі материалдары Бәбіш мола қаласына 2018 ж. жүргізілген зерттеу жұмыстары 


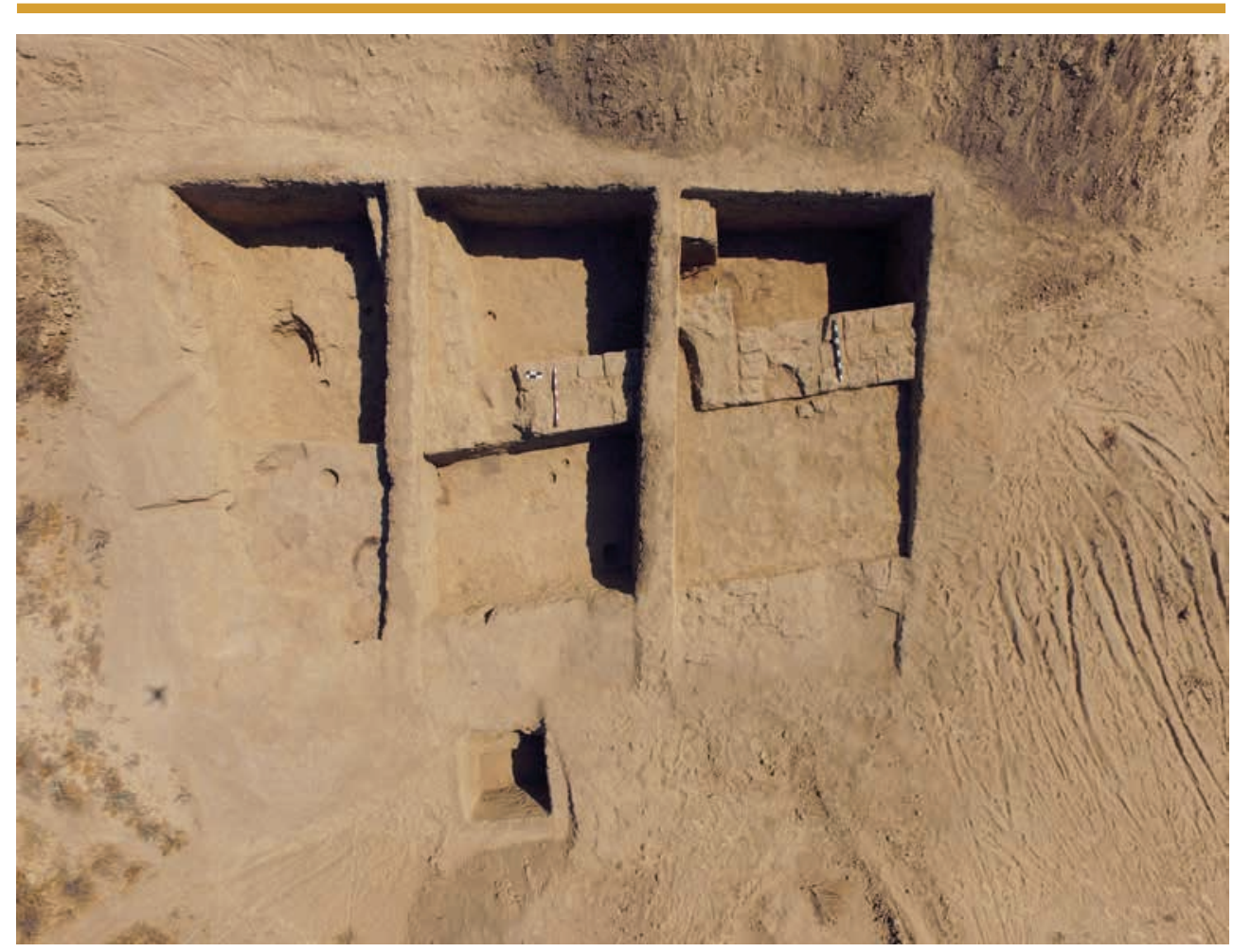

Сур. 3. Цитадельге санылган қ̧азба. Ж.Р. Утубаевтың фотосы

Fig. 3. Excavation at the citadel. Photo by Zh.R. Utubayev

кезінде табылған остеологиялық материалдар болып табылады. Қазба барысында жалпы 231 дана жануар сүйегі табылса, соның ішінде 87 данасы сүтқоректі жануардың асықтарына тиесілі. Асықтарды камералдық өңдеу және талдау барысында, басым бөлігінің қуысмүйізділер (Bovidae) тұқымдасына жататын ақбөкен (Saiga tatarica) асықтары екендігі анықталды. Жалпы асықтардың ішінде бірнеше қой (Ovis) мен ешкі (Capra) асықтары да кездеседі. Ақбөкен асықтарының ішінде сегіз асық өңдеуге түскен. Оның ішінде алты асықтың бетіне түрлі сызбалар жасалған. Бірнеше ақбөкен және қой асықтарының медиальды қырына тесік жасалған.

Жануар асықтарының өзара айырмашылықтары, оның ішінде ақбөкен асықтарының дорсальды бөлігіндегі ерекшеліктері
В. Громованың анықтамасы арқылы талданды [Громова, 1960, с. 114115]. Асықтардың морфометриялық өлшемдері А. Дриштің әдістемесіне сүйеніп талданды [Driesch, 1976, p. 52-101]. Өлшемдер негізінен латеральды қырының ұзындығы, медиальды қырының ұзындығы, дистальды ені және латеральдымедиальды қимасының ені бойынша алынды. Яғни Бәбіш мола қаласынан табылған асықтардың саггитальды қимасының орнына латеральдымедиальды қимасының ені есепке алынып отыр. Ескере кететін жағдай, палеонтологиялық материалдарды морфометриялық зерттеу тәсілдері әлі күнге бір жақты емес. Мәселен жануар асықтарын, оның ішінде жұптұяқты жануар асықтарының өлшемдері А. Дриштің әдістемесіне сүйеніп жасалса, жылқы, құлан 


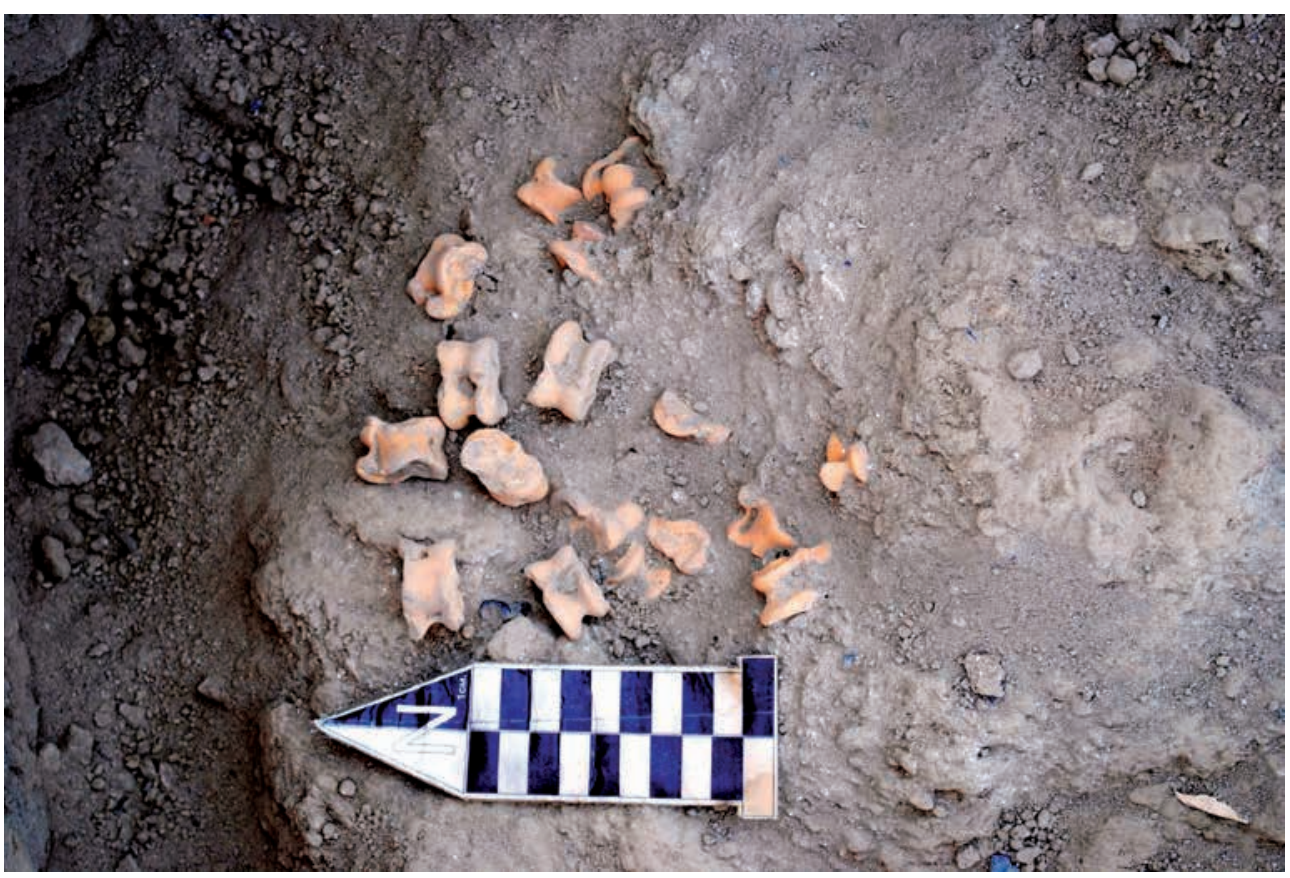

Сур. 4. Ақъбөкен асықтары. Қазба барысы. Ж.Р. Утубаевтың фотосы

Fig. 4. Astragalus saiga. Excavation process. Photo by Zh.R. Utubayev

секілді жануардың асықтары В. Эйзенман жасаған әдістемеге сүйенеді [Eisenmann, 1982, p. 75-103]. Біздің мысалда А. Дриштің талдау әдістері негізге алынып отыр.

Асықтардың жалпь сипатmаMacbl

Қазба барысында табылған асықтардың жалпы саны 87 дана (сур. 5). Оның ішінде бірінші шұңқырдан табылған 64 дана, екінші топтамада 23 дана. Археозоологиялық талдау нәтижесінде асықтар жануардың төрт түріне тиесілі екендігі белгілі болды (кесте 1-2).
1. Сол аяққа тиесілі 36 дана асықтың кестеде көрсетілгендей екеуі үй жануарына тиесілі. Қой асығының латеральды бөлігінің проксимальды блогында арнайы жасалған тесік бар. Тесіктің диаметрі 2,74×3,13 мм құрайды. Ақбөкеннің бір асығында кертілген сызықты із сақталған, ал 3 асықтың проксимальды блогтағы латеральды бөлігінің бұрыштары кертілген. Жалпы мұндай белгілерді ақбөкен асығының көпшілігінен байқауға болады. Ақбөкеннің үш асығында ерекше сызықты белгілер сақталған. Асықтардың плантарлы

Кесте 1 - Бірінші топтамадағы асықтар кешені Table 1 - Talus bones from the first group

\begin{tabular}{|l|c|c|c|}
\hline Жануар түрі & Асық саны & Оң аяқ & Сол аяқ \\
\hline Ақбөкен (Saiga tatarica) & 62 & 28 & 34 \\
\hline Қой (Ovis) & 1 & - & + \\
\hline Ешкі (Capra) & 1 & - & + \\
\hline
\end{tabular}




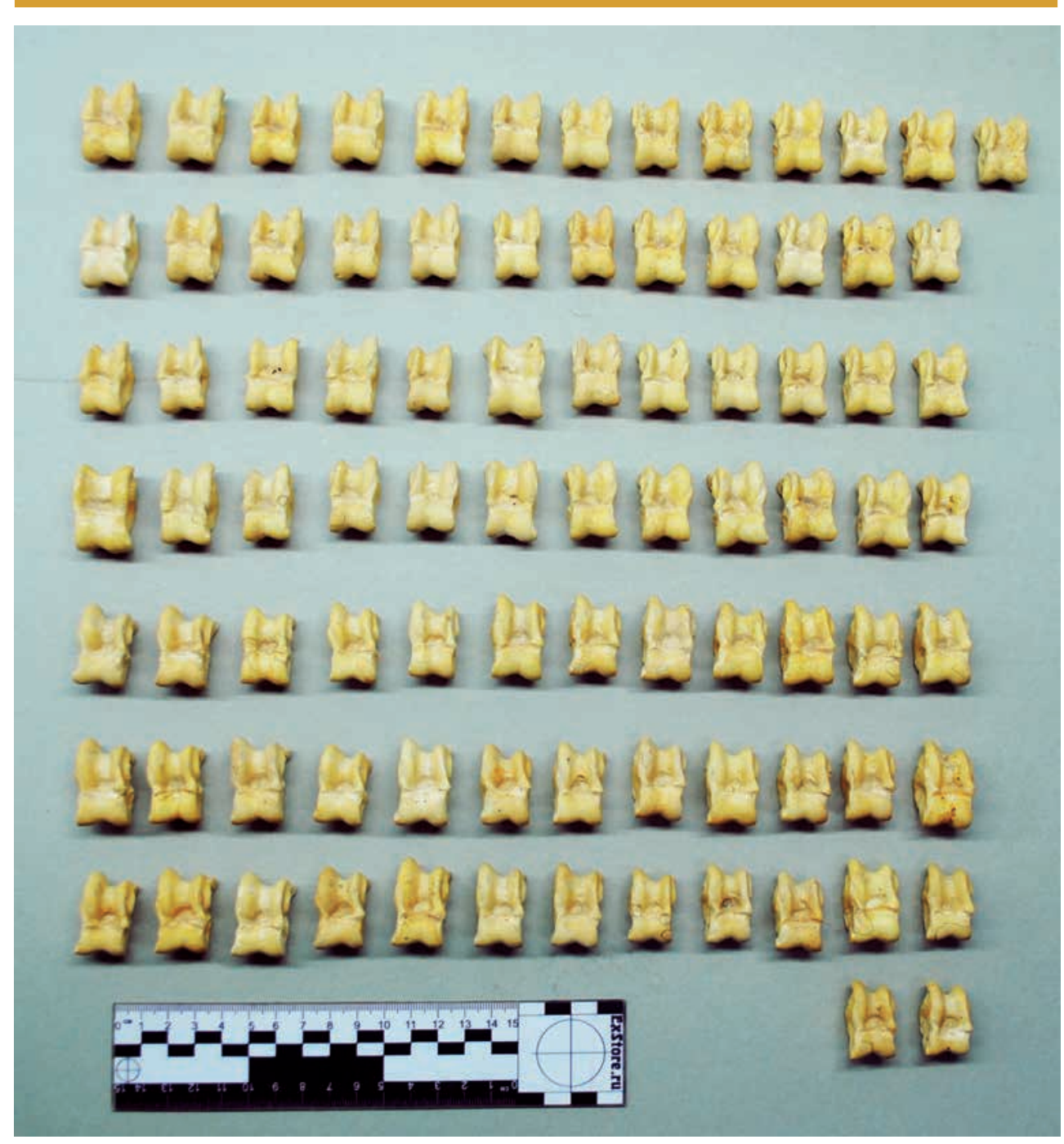

Сур. 5. Бәбіш мола. Ақббөкен асықтары. М.С. Шагирбаевтың фотосы

Fig. 5. Babish mola. Astragalus saiga. Photo by M.S. Shagirbayev

бетінде бірнеше сызықты іздер кесе көлденең және тігінен орналасқан. Ақбөкенге тиесілі бір дана асықта да қой асығы секілді тесік жасалған.

2. Оң аяққа тиесілі 28 дана асықтың барлығы ақбөкенге тиесілі. Оның ішінде 4 асықтың плантарлы, дорсальды, проксимальды және дистальды блоктары мен бөліктерінде ұсақ сызық мен кесік іздер байқалады. 2 дана асықтың плантарлы бетінде «зигзаг» және «торкөз» тәріздес сызықты іздер салынған.
Торкөз салынған асықтың дорсальды бөлігінің дистальды блогында ұсақ кесіктің ізі сақталған. Біздің ойымызша ұсақ кесік сызықтар жануарды сою кезінде пышақ немесе басқа да өткір құралған қалған. Ал плантарлы бөліктегі сызықтар арнайы мақсатта салынған.

1. Сол аяққа тиесілі 10 асықтың 8-i ақбөкенге (Saiga tatarica), 2-i қарақұйрыққа (Gazella subgutturosa) тиесілі. Ақбөкен асығының 1 данасының дистальды бло- 
Кесте 2 - Екінші топтама (23 асық)

Table 2 - Second group (23 astragalus)

\begin{tabular}{|l|c|c|c|}
\hline Жануар түрі & Асық саны & Оң аяқ & Сол аяқ \\
\hline Ақбөкен (Saiga tatarica) & 21 & 13 & 8 \\
\hline Қарақұйрық (Gazella subgutturosa) & 2 & - & + \\
\hline
\end{tabular}

гында кесік ізі байқалады. Қарақұйрық асығының 1 данасының дорсальды бетінде екі кесік орны сақталған.

2. Оң аяққа тиесілі 13 асықтың барлығы дерлік ақбөкенге тиесілі. Оның ішінде 3 данасында ұсақ кесіксызықтар сақталған. Кесікті сызықтар асықтың дорсальды бөлігіне түскен. Жоғарыда атап өткендей аталған кесікті сызықтар жануардың етін бөлшектеу кезінде түсуі әбден мүмкін. Жалпы сықтың дорсальды бөлігіне кесікті сызықтардың жиі түсуі, жануардың асықты жілігінен сирақты ажырату кезінде, плантарлы яғни каудальды бағытқа қисайтып, дорсальды бөліктен сіңірді кеседі. Осы сәтте жоғарыда аталған іздердің түсуі ықтималдылығы жоғарылайды. Ақбөкеннің бір асығының плантарлы бетінде ерекше сызықты белгілер сақталған. Плантарлы бөліктің қақ ортасында аздап ойыс жасап, соған төрт тараптан 3 сызықтан келіп қосылған. Тура бір күн шапағын шашып тұрған көрініске жақын етіп жасалған.

талдау

Асықтардь м морфометрияльқ қ

Жалпы қуыс мүйізділер тұқымдасына жататын ақбөкен мен қарақұйрықтың кейбір жекелеген сүйектерін ажырату өте қиын. Оның ішінде асықтары бір-біріне қатты ұқсайды. Қуысмүйізділер (Bovidae) тұқымдастарының ішіндегі ақбөкен немесе киік (Saiga tatarica) асықтарын жайрандар немесе қарақұйрық (Gazella subgutturosa) асығынан ажыратудың бірнеше белгілері бар. Аталған морфологиялық белгілерді В. Громова [1960, с. 114-115] төмендегідей ерекшеліктермен сипаттайды:

- Ақбөкен асығының дорсальды бөлігінің жоғарғы блогындағы ішкі жотасы сыртқа қарай едәуір ауытқиды. Бұл ерекшелік жайран немесе қарақұйрық асықтарында болмайды.

- Ақбөкен асығының ішкі жотасының дөңесі жайран мен зерен асықтарына қарағанда, сыртқы жотаның төменгі тұйықталар жерімен биік білікше арқылы жалғасады.

Ақбөкен асығының куб тәрізді шұңқырдындағы сыртқа шығаратын каналдың жоғарғы шеті сүйектің білігіне перпендикуляр болca, жайранда білікке қарай қисайып орналасқан.

- Ақбөкен асығында ішкі жотадағы сыртқы шетінің сызығы жотаға келіп дөңестеледі және жотаның өзі мұқалып қалған. Басқа қуысмүйізділерде (Bovidae) бұл сызық бүгілген, ал жотасы сүйірленіп келуімен ерекшеленеді.

БәбішМолақаласынантабылған ақбөкен,ішінарақарақұйырқ, қойжәне ешкі асықтарына морфометриялық зерттеу 4 өлшем негізінде жүргізілді (кесте 3-8):

1. Латеральды ұзындығы бойынша;

2. Медиальды ұзындығы бойынша;

3. Латеральды-медиальды бөліктің көлденең қимасы бойынша; 
Шагирбаев М.С., Утубаев Ж.Р. Жануар асықтарының археозоологиялық зерттелуі

4. $\quad$ Плантарлы-дорсальды

бөліктің көлденең қимасы бойынша. Ақ̧бөкен асықтарыныңц

вариациялық қ̧атарына сараптама
Ақбөкен

асықтарының вариациялық қатарына жүргізілген сараптаманың негізгі мақсаты асықтың өлшенген бөлігіндегі өлшем

Кесте 3 - Ақбөкеннің оң аяғына тиесілі асықтар өлшемі (10 дана)

Table 3 - Measurement of the talus bones belonging to the right side of the legs (10 pcs)

\begin{tabular}{|l|l|l|l|l|}
\hline № & $\begin{array}{c}\text { Ұзындығы } \\
\text { (латеральды) (мм) }\end{array}$ & $\begin{array}{c}\text { Ұзындығы } \\
\text { (медиальды) (мм) }\end{array}$ & $\begin{array}{c}\text { Латеральды- } \\
\text { медиальды ені } \\
\text { (мм) }\end{array}$ & $\begin{array}{c}\text { дорсальды- } \\
\text { плантарлы } \\
\text { кммасы (мм) }\end{array}$ \\
\hline 1 & 32,5 & 31 & 18,5 & 18,1 \\
\hline 2 & 32,5 & 30 & 20 & 19 \\
\hline 3 & 29 & 27,3 & 16,4 & 16 \\
\hline 4 & 32 & 30 & 19 & 18,5 \\
\hline 5 & 30,5 & 28,5 & 18,5 & 17 \\
\hline 6 & 29 & 27,1 & 17,5 & 16,3 \\
\hline 7 & 32 & 29 & 18,5 & 18 \\
\hline 8 & 33,5 & 30,5 & 20 & 18,1 \\
\hline 9 & 30 & 28 & 17,5 & 15,5 \\
\hline 10 & 32 & 29 & 20 & 17,5 \\
\hline $\mathbf{M :}$ & $\mathbf{3 1 , 3}$ & $\mathbf{2 9 , 0 4}$ & $\mathbf{1 8 , 5 9}$ & $\mathbf{1 7 , 4}$ \\
\hline
\end{tabular}

Кесте 4 - Ақбөкеннің сол аяғына тиесілі асықтар өлшемі (13 дана)

Table 4 - Measurement of the talus bones belonging to the left side of the legs (13 pcs)

\begin{tabular}{|c|c|c|c|c|}
\hline$№$ & $\begin{array}{c}\text { Ұзындығы } \\
\text { (латеральды) } \\
(\text { мм })\end{array}$ & $\begin{array}{c}\text { Ұзындығы } \\
\text { (медиальды) } \\
(\text { мм) }\end{array}$ & $\begin{array}{c}\text { Латеральды- } \\
\text { медиальды ені (мм) }\end{array}$ & $\begin{array}{c}\text { Дорсальды- } \\
\text { плантарлы } \\
\text { қимасы } \\
\text { (мм) }\end{array}$ \\
\hline 1 & 31,5 & 29,5 & 18,5 & 17,5 \\
\hline 2 & 30 & 28 & 18,5 & 16 \\
\hline 3 & 31 & 30 & 18 & 18 \\
\hline 4 & 33,5 & 31,5 & 20,5 & 17,5 \\
\hline 5 & 32 & 28,5 & 18,1 & 17 \\
\hline 6 & 30 & 28 & 19 & 18,5 \\
\hline 7 & 31 & 28,5 & 18,5 & 17,5 \\
\hline 8 & 30 & 27,8 & 18,4 & 17,5 \\
\hline 9 & 31 & 29,5 & 19 & 16,1 \\
\hline 10 & 30,5 & 28 & 18 & 17,5 \\
\hline 11 & 29,5 & 27 & 18 & $\mathbf{1 7 , 2 5}$ \\
\hline 12 & 31,9 & 29 & $\mathbf{1 8 , 6 6}$ & 17 (қой) \\
\hline М: & $\mathbf{3 0 , 9 9}$ & $\mathbf{2 8 , 7 7}$ & $21($ қой $)$ & \\
\hline 13 & 33 (қой) & 33 (қой) & & \\
\hline
\end{tabular}




\section{ҚАЗАҚСТАН АРХЕОЛОГИЯСЫ № 4 (6) 2019}

Кесте 5 - Ақбөкеннің сол аяғына тиесілі асықтар өлшемі (36 дана)

Table 5 - Measurement of the talus bones belonging to the left side of the legs (36 pcs)

\begin{tabular}{|c|c|c|c|c|}
\hline № & $\begin{array}{c}\text { Ұзындығы } \\
\text { (латеральды) } \\
\text { (мм) } \\
\end{array}$ & $\begin{array}{c}\text { Ұзындығы } \\
\text { (медиальды) } \\
\text { (мм) } \\
\end{array}$ & $\begin{array}{c}\text { Латеральды- } \\
\text { медиальды ені } \\
\text { (мм) } \\
\end{array}$ & $\begin{array}{c}\text { Дорсальды- } \\
\text { плантарлы қимасы } \\
\text { (мм) }\end{array}$ \\
\hline 1 & 29 & 27,9 & 18,1 & 15,5 \\
\hline 2 & 29,1 & 27,9 & 18,1 & 16,4 \\
\hline 3 & 30,1 & 27,5 & 18,9 & 16,2 \\
\hline 4 & 29,2 & 26,9 & 17,1 & 16,1 \\
\hline 5 & 32 & 30 & 19 & 18,1 \\
\hline 6 & 32 & 30 & 19 & 18,5 \\
\hline 7 & 30,5 & 29 & 17,5 & 17 \\
\hline 8 & 31,5 & 28 & 18 & 17,5 \\
\hline 9 & 31 & 28,5 & 18 & 16,5 \\
\hline 10 & 31 & 28,5 & 18,1 & 17,1 \\
\hline 11 & 29 & 27 & 16,5 & 16 \\
\hline 12 & 29 & 27 & 17 & 16,5 \\
\hline 13 & 30 & 28 & 17,4 & 17 \\
\hline 14 & 30 & 28,5 & 17,5 & 17,1 \\
\hline 15 & 32,5 & 30,1 & 19,5 & 17,5 \\
\hline 16 & 29 & 26,5 & 16,9 & 15,9 \\
\hline 17 & 30 & 27,9 & 17 & 16 \\
\hline 18 & 32,1 & 29,5 & 19 & 17,9 \\
\hline 19 & 32 & 30 & 18,5 & 19 \\
\hline 20 & 31 & 30 & 18,5 & 17,5 \\
\hline 21 & 29 & 26,5 & 16,1 & 16 \\
\hline 22 & 30,5 & 29 & 19 & 18 \\
\hline 23 & 30 & 27,8 & 17,5 & 17 \\
\hline 24 & 31 & 29 & 18,1 & 17 \\
\hline 25 & 31 & 29 & 18,1 & 17 \\
\hline 26 & 33,1 & 30,9 & 20 & 18,5 \\
\hline 27 & 30 & 27 & 17 & 16 \\
\hline 28 & 27,9 & 26 & 16 & 16 \\
\hline 29 & 33 & 30,5 & 19,5 & 17,5 \\
\hline 30 & 30 & 28 & 17,5 & 18 \\
\hline 31 & 29 & 27 & 17,1 & 16 \\
\hline 32 & 31,5 & 29 & 18,5 & 17,5 \\
\hline 33 & 29,5 & 27 & 17,5 & 16,5 \\
\hline 34 & 32 & 29,5 & 18,5 & 18,1 \\
\hline 35 & 30 & 26,9 & 17,5 & 17 \\
\hline M: & 30,5 & 28,33 & 17,92 & 17,01 \\
\hline 36 & 32 (кой) & 30,9 (қой) & 20,5 (қой) & 17,5 (қой) \\
\hline
\end{tabular}


Шагирбаев М.С., Утубаев Ж.Р. Жануар асықтарының археозоологиялық зерттелуі

Кесте 6 - Ақбөкеннің оң аяғына тиесілі асықтар өлшемі (28 дана)

Table 6 - Measurement of the talus bones belonging to the right side of the legs ( $28 \mathrm{pcs}$ )

\begin{tabular}{|c|c|c|c|c|}
\hline № & $\begin{array}{l}\text { Ұзындығы } \\
\text { (латеральды) } \\
\text { (мм) }\end{array}$ & $\begin{array}{c}\text { Ұзындығы } \\
\text { (медиальды) } \\
\text { (мм) }\end{array}$ & $\begin{array}{c}\text { Латеральды- } \\
\text { медиальды ені (мм) }\end{array}$ & $\begin{array}{c}\text { Дорсальды-плантарлы } \\
\text { қимасы } \\
\text { (мм) }\end{array}$ \\
\hline 1 & 30 & 27 & 17,1 & 16 \\
\hline 2 & 30 & 28 & 17,5 & 17 \\
\hline 3 & 31 & 29 & 18 & 17 \\
\hline 4 & 34 & 31 & 20 & 19,5 \\
\hline 5 & 30,5 & 28 & 18 & 16,9 \\
\hline 6 & 32,1 & 30 & 18 & 18 \\
\hline 7 & 32,9 & 30 & 19,5 & 19 \\
\hline 8 & 30,5 & 29 & 18,5 & 16,9 \\
\hline 9 & 31 & 29,1 & 17 & 17 \\
\hline 10 & 27,6 & 26,9 & 16 & 15,5 \\
\hline 11 & 31,1 & 28,1 & 18,1 & 17,2 \\
\hline 12 & 32,1 & 32 & 18,5 & 18,2 \\
\hline 13 & 31 & 29 & 18,5 & 17 \\
\hline 14 & 32,5 & 30 & 18 & 19 \\
\hline 15 & 30,5 & 28 & 18,5 & 16,5 \\
\hline 16 & 30 & 28 & 18,1 & 17 \\
\hline 17 & 30 & 28 & 18 & 16 \\
\hline 18 & 30,5 & 29 & 17,5 & 16,1 \\
\hline 19 & 31 & 29 & 19 & 17,5 \\
\hline 20 & 32,5 & 30 & 19 & 19 \\
\hline 21 & 30 & 27 & 17,5 & 16,5 \\
\hline 22 & 31,5 & 28,5 & 18 & 17 \\
\hline 23 & 31 & 28 & 18 & 16,5 \\
\hline 24 & 31 & 28,6 & 17,8 & 16,5 \\
\hline 25 & 30 & 27 & 18 & 17 \\
\hline 26 & 31,5 & 28,5 & 18 & 18,1 \\
\hline 27 & 28 & 26 & 17 & 15,5 \\
\hline 28 & 32 & 30 & 20 & 18,5 \\
\hline M: & 30,92 & 28,66 & 18,11 & 17,21 \\
\hline
\end{tabular}

Кесте 7 - Асық өлшемдерінің ортақ арифметикалық мөлшері (М)

Table 7-Arithmetic mean of the size of the talus bones(M)

\begin{tabular}{|l|c|c|c|c|}
\hline \multicolumn{1}{|c|}{ Атауы } & $\begin{array}{c}\text { Ұзындығы } \\
\text { (латер.) } \\
\text { (мм) }\end{array}$ & $\begin{array}{c}\text { Ұзындығы } \\
\text { (медиал) } \\
\text { (мм) }\end{array}$ & $\begin{array}{c}\text { Латера- } \\
\text { медиаль } \\
\text { ені } \\
\text { (мм) }\end{array}$ & $\begin{array}{c}\text { Дорсальды- } \\
\text { плантар. } \\
\text { қимасы } \\
\text { (мм) }\end{array}$ \\
\hline Оң аяққа тиесілі асықтар (10) & $\mathbf{3 1 , 3}$ & $\mathbf{2 9 , 0 4}$ & $\mathbf{1 8 , 5 9}$ & $\mathbf{1 7 , 4}$ \\
\hline Сол аяққа тиесілі асықтар (13) & $\mathbf{3 0 , 9 9}$ & $\mathbf{2 8 , 7 7}$ & $\mathbf{1 8 , 6 6}$ & $\mathbf{1 7 , 2 5}$ \\
\hline Сол аяққа тиесілі асықтар (36) & $\mathbf{3 0 , 5}$ & $\mathbf{2 8 , 3 3}$ & $\mathbf{1 7 , 9 2}$ & $\mathbf{1 7 , 0 1}$ \\
\hline Оң аяққа тиесілі асықтар (28) & $\mathbf{3 0 , 9 2}$ & $\mathbf{2 8 , 6 6}$ & $\mathbf{1 8 , 1 1}$ & $\mathbf{1 7 , 2 1}$ \\
\hline
\end{tabular}


Кесте 8 - Бәбіш Мола қаласынан табылған ақбөкен асықтарының өлшемдері (мм) және пропорциясы \%\%

Table 8 - Dimensions $(\mathrm{mm})$ and proportions $(\% \%)$ of saiga talus bones found from the Babish Mola settlement

\begin{tabular}{|c|c|c|c|c|c|}
\hline Белгілер & $\sqrt{ } \mathbf{n}-1$ & Lim & $\mathbf{M}$ & $\mathbf{M} \pm \mathbf{m}$ & $\mathbf{o}^{\prime}$ \\
\hline \multicolumn{6}{|c|}{ Ақбөкеннің оң аяғына тиесілі асықтар n=10 } \\
\hline Латеральды ұзындығы & 2,16 & $29-32,5$ & 31,3 & $31,3 \pm 2,17$ & 4,7 \\
\hline Медиальды ұзындығы & 2,16 & $31-27,3$ & 29,04 & $29,04 \pm 1,75$ & 3,78 \\
\hline Латеральды-медиальды ені (мм) & 2,16 & $20-16,4$ & 18,59 & $18,59 \pm 0$ & 0 \\
\hline Дорсальды-плантарлы қимасы (мм) & 2,16 & $19-15,5$ & 17,4 & $17,4 \pm 1,89$ & 4,10 \\
\hline \multicolumn{6}{|c|}{ Ақбөкеннің сол аяғына тиесілі асықтар n=12 } \\
\hline Латеральды ұзындығы & 2.46 & $31,9-29,5$ & 30,99 & $30,99 \pm 1,91$ & 4,71 \\
\hline Медиальды ұзындығы & 2.46 & $27-31,5$ & 28,77 & $28,77 \pm 1,62$ & 4,00 \\
\hline Латеральды-медиальды ені (мм) & 2.46 & $20,5-18$ & 18,66 & $18,66 \pm 0.99$ & 2,45 \\
\hline Дорсальды-плантарлы қимасы (мм) & 2.46 & $18,5-16$ & 17,25 & $17,25 \pm 0$ & 0 \\
\hline \multicolumn{6}{|c|}{ Ақбөкеннің сол аяғына тиесілі асықтар n=35 } \\
\hline Латеральды ұзындығы & 5.91 & $33,1-27,9$ & 30,5 & $30,5 \pm 1,29$ & 7,65 \\
\hline Медиальды ұзындығы & 5.91 & $30,9-26,5$ & 28,3 & $28,3 \pm 1,28$ & 7,59 \\
\hline Латеральды-медиальды ені (мм) & 5.91 & $20-16$ & 17,92 & $17,9 \pm 0,94$ & 5,61 \\
\hline Дорсальды-плантарлы қимасы (мм) & 5.91 & $18,5-15,5$ & 17,1 & $17,1 \pm 0,91$ & 5,42 \\
\hline \multicolumn{6}{|c|}{ Ақбөкеннің оң аяғына тиесілі асықтар n=28 } \\
\hline Латеральды ұзындығы & 4,29 & $34-27,6$ & 30,92 & $30,92 \pm 1,51$ & 6,49 \\
\hline Медиальды ұзындығы & 4,29 & $32-26$ & 28,66 & $28,66 \pm 1,61$ & 6,90 \\
\hline Латеральды-медиальды ені (мм) & 4,29 & $20-16$ & 18,11 & $18,11 \pm 1,05$ & 4,52 \\
\hline Дорсальды-плантарлы қимасы (мм) & 4,29 & $19,5-15,5$ & 17,21 & $17,21 \pm 1.3$ & 5,60 \\
\hline
\end{tabular}

бірліктің қайталап кездесу санын анықтау. Статистикалық зерттеу әдістеріндегі ортақ формулаға сәйкес, төмендегі 4 өлшем өзіндік шартты белгілермен көрсетілді:

$\mathrm{X}_{1}$-Латеральды ұзындығы

$\mathrm{X}_{2}$-Медиальды ұзындығы ені (мм)

$\mathrm{X}_{3}$ - Латеральды-медиальды

$\mathrm{X}_{4}$ - Дорсальды-плантарлы қимасы (мм).
Ақбөкен

асықтарының ішінде оң аяққа тиесілі 10 асықтың вариациялық қатарында өзара ұқсастықтар аса көп емес (кесте 9). Зерттеу жұмысы көрсетіп отырғандай латеральды бөлігінде $\left(\mathrm{X}_{1}\right)$ бірдей өлшемдер жиі кездессе, керісінше дорсальды-плантарлы қимасында $\left(\mathrm{X}_{4}\right)$ бір ғана өлшем ұқсастық тауып, басқалары әртүрі өлшемдерді көрсетіп отыр. Жалпы жануар сүйектерін 
Шагирбаев М.С., Утубаев Ж.Р. Жануар асықтарының археозоологиялық зерттелуі

Кесте 9 - Ақбөкеннің оң аяғына тиесілі асық өлшемдерінің (n=10) вариациялық қатары

Table 9 - Variation row of talus bones $(n=10)$ from the right side of the saiga legs

\begin{tabular}{|c|c|}
\hline Латеральды ұзындығы (X, & Кездесу жиілігі (f) \\
\hline 32 & 3 \\
\hline 32,5 & 2 \\
\hline 29 & 2 \\
\hline 30 & 1 \\
\hline 30,5 & 1 \\
\hline 33,5 & 1 \\
\hline Медиальды ұзындығы $\left(\mathrm{X}_{2}\right)$ & Кездесу жиілігі (f) \\
\hline 30 & 2 \\
\hline 29 & 2 \\
\hline 31 & 1 \\
\hline 27,3 & 1 \\
\hline 28,5 & 1 \\
\hline 27,1 & 1 \\
\hline 30,5 & 1 \\
\hline 28 & 1 \\
\hline Латеральды-медиальды ені $\left(\mathrm{X}_{3}\right)$ & Кездесу жиілігі (f) \\
\hline 20 & 3 \\
\hline 18,5 & 3 \\
\hline 17,5 & 2 \\
\hline 19 & 1 \\
\hline 16,4 & 1 \\
\hline Дорсальды-плантарлы қимасы $\left(\mathrm{X}_{4}\right)$ & Кездесу жиілігі (f) \\
\hline 18,1 & 2 \\
\hline 19 & 1 \\
\hline 18,5 & 1 \\
\hline 17 & 1 \\
\hline 16 & 1 \\
\hline 16,3 & 1 \\
\hline 17,5 & 1 \\
\hline 15,5 & 1 \\
\hline 18 & 1 \\
\hline
\end{tabular}


морфометриялық зерттеуде ескеретін жағдай, сүйектерді өлшеудің нақты заңдылығы толық қалыптаспаған. Мәселен А.В. Дриштің [Driesch, 1976, p. 52-101] остеометриялық өлшеу методикасы көбіне жыртқыш аңдар, ipi үй жануарларының сүйектерін өлшеуде белгілер санын көбірек қамтыса, В.Эйзенманның [Eisenmann, Karchound, 1982, p. 75-103] зерттеу тәсілдерінде керісінше сүйектерді өлшеудің басқа әдістерін ұсынады. Біздің тарапымыздан жүргізілген морфометриялық талдауда асықтардың саггитальды қимасы емес, дорсальды-плантарлы қимасы есепке алынды. Нәтижесінде қуысмүйізділер (Bovidae) тұқымдасына жататын ақбөкен (Saiga tatarica) асықтарының дорсальды-плантарлы

қимасында өзара ұқсастықтарға қарағанда, айырмашылықтар көп болатыны белгілі болып отыр.

$\mathrm{X}_{1}$ белгісі бойынша ең көп ұшырасқан өлшемдер: 32,5-32 мм;

$\mathrm{X}_{2}$ белгісі бойынша ең көп ұшырасқан өлшемдер: 29-30 мм;

$\mathrm{X}_{3}$ белгісі бойынша ең көп ұшырасқан өлшемдер: 18,5-20 мм;

$\mathrm{X}_{4}$ белгісі бойынша ең көп ұшырасқан өлшемдер: 18-19 мм.

Ақбөкеннің сол аяғына тиесілі асықтардың морфометриялық өлшемдеріндегі вариациялық қатарда оң аяқ асықтарына қарағанда біршама айырмашылықтар байқалады (кесте 10). Мәселен, асықтардың дорсальды-плантарлы қимасындағы

Кесте 10 - Ақбөкеннің сол аяғына тиесілі асық өлшемдерінің (n=12) вариациялық қатары

Table 10 - Variation row of talus bones $(n=12)$ from the left part of the saiga legs

\begin{tabular}{|c|c|}
\hline Латеральды ұзындығы $\left(\mathrm{X}_{1}\right)$ & Кездесу жиілігі (f) \\
\hline 31 & 3 \\
\hline 30 & 1 \\
\hline 30,5 & 1 \\
\hline 29,5 & 1 \\
\hline 31,9 & 1 \\
\hline 31,5 & 1 \\
\hline 33,5 & 1 \\
\hline 32 & Кездесу жиілігі (f) \\
\hline 28 & 3 \\
\hline 28,5 & 2 \\
\hline 29,5 & 2 \\
\hline 30 & 1 \\
\hline 31,5 & 1 \\
\hline 27,8 & 1 \\
\hline 27 & 1 \\
\hline 29 & 1 \\
\hline Медиальды ұзындығы $\left(\mathrm{X}_{2}\right)$ & Кездесу жиілігі (f) \\
\hline 18,5 & 3 \\
\hline 18 & 3 \\
\hline 19 & 2 \\
\hline
\end{tabular}


Шагирбаев М.С., Утубаев Ж.Р. Жануар асықтарының археозоологиялық зерттелуі

\begin{tabular}{|c|c|}
\hline 20,5 & 1 \\
\hline 18,1 & 1 \\
\hline 18,4 & 1 \\
\hline 19,5 & 1 \\
\hline 17,5 & Кездесу жиілігі (f) \\
\hline 18 & 2 \\
\hline 16 & 2 \\
\hline 17 & 1 \\
\hline 18,5 & 1 \\
\hline 16,1 & 1 \\
\hline
\end{tabular}

бірдей өлшемдерді жиі кездеседі. Оң аяққа тиесілі асықтарда мұндай ұқсастықтар тек бір рет қана кездескен. Сол аяққа тиесілі қалған $\mathrm{X}_{1}, \mathrm{X}_{2}$, $\mathrm{X}_{3}$ өлшемдерінде де бірдей белгілер жиі көрініс тауып отыр. Жалпы асықтардағы мұндай ерекшеліктер өз кезегінде белгілі бір заңдылықтардан тууы мүмкін екендігін жоққа шығармайды.

$\mathrm{X}_{1}$ белгісі бойынша ең көп ұшырасқан өлшемдер: 30-31 мм;

$\mathrm{X}_{2}$ белгісі бойынша ең көп ұшырасқан өлшемдер: 28-28,5 мм; $\mathrm{X}_{3}$ белгісі бойынша ең көп ұшырасқан өлшемдер: 18-18,5 мм;

$\mathrm{X}_{4}$ белгісі бойынша ең көп ұшырасқан өлшемдер: 17,5-18 мм.

Ақбөкеннің сол аяғына тиесілі 35 дана асықтың вариациялық құрамында бірдей белгілердің жиі кездесуі асық санының көптігімен байланысты болуы мүмкін. Бірақ салыстырмалы түрде орта өлшемдегі асықтарда бірдей өлшемдер жиі кездеседі (кесте 11). Жалпы көлемі

Кесте 11 - Ақбөкеннің сол аяғына тиесілі асық өлшемдерінің (n=35) вариациялық қатары

Table 11 - Variation row of talus bones $(n=35)$ from the left part of the saiga legs

\begin{tabular}{|c|c|}
\hline Латеральды ұзындығы $\left(\mathrm{X}_{1}\right)$ & Кездесу жиілігі (f) \\
\hline 30 & 7 \\
\hline 29 & 6 \\
\hline 31 & 5 \\
\hline 32 & 4 \\
\hline 30,5 & 2 \\
\hline 29,1 & 1 \\
\hline 30,1 & 1 \\
\hline 29,2 & 1 \\
\hline 31,5 & 1 \\
\hline 32,5 & 1 \\
\hline 32,1 & 1 \\
\hline 33,1 & 1 \\
\hline 27,9 & 1 \\
\hline 33 & 1 \\
\hline 31,5 & 1 \\
\hline 29,5 & 1 \\
\hline
\end{tabular}




\section{ҚАЗАҚСТАН АРХЕОЛОГИЯСЫ № 4 (6) 2019}

\begin{tabular}{|c|c|}
\hline Медиальды ұзындығы $\left(X_{2}\right)$ & Кездесу жиілігі (f) \\
\hline 29 & 5 \\
\hline 27 & 5 \\
\hline 30 & 4 \\
\hline 28,5 & 3 \\
\hline 27,9 & 3 \\
\hline 28 & 3 \\
\hline 26,9 & 2 \\
\hline 26,5 & 2 \\
\hline 29,5 & 2 \\
\hline 27,5 & 1 \\
\hline 30,1 & 1 \\
\hline 27,8 & 1 \\
\hline 30,9 & 1 \\
\hline 26 & 1 \\
\hline 30,5 & 1 \\
\hline Латеральды-медиальды ені $\left(\mathrm{X}_{3}\right)$ & Кездесу жиілігі (f) \\
\hline 17,5 & 6 \\
\hline 18,1 & 5 \\
\hline 18,5 & 4 \\
\hline 19 & 4 \\
\hline 17 & 3 \\
\hline 19,5 & 2 \\
\hline 17,1 & 2 \\
\hline 18 & 2 \\
\hline 18,9 & 1 \\
\hline 16,5 & 1 \\
\hline 17,4 & 1 \\
\hline 16,9 & 1 \\
\hline 16,1 & 1 \\
\hline 20 & 1 \\
\hline 16 & 1 \\
\hline Дорсальды-плантарлы қимасы $\left(\mathrm{X}_{4}\right)$ & Кездесу жиілігі (f) \\
\hline 16 & 6 \\
\hline 17 & 6 \\
\hline 17,5 & 5 \\
\hline 16,5 & 3 \\
\hline 17,1 & 2 \\
\hline 18 & 2 \\
\hline 18,1 & 2 \\
\hline 18,5 & 2 \\
\hline 15,5 & 1 \\
\hline 16,4 & 1 \\
\hline 16,2 & 1 \\
\hline 16,1 & 1 \\
\hline 15,9 & 1 \\
\hline 17,9 & 1 \\
\hline 19 & 1 \\
\hline
\end{tabular}


Шагирбаев М.С., Утубаев Ж.Р. Жануар асықтарының археозоологиялық зерттелуі

үлкен асықтардың өлшемдері көбіне индивидуальды ерекшелігін сақтап қалады. Мүмкін бұл жануардың жасы келгенге дейінгі тірек қимыл жүйесінің жеке даму ерекшеліктерімен және жынысына тікелей байланысты болуы мүмкін. Дегенмен жоғарыда атап өткендей белгілі бір жас мөлшеріне тиесілі асықтарда ортақ өлшемдер жиі кездеседі. Бұл зерттеу нәтижелері ақбөкендердің көбіне орта жасқа дейінгі түрлері ауланғанын дәлелдейді.
$\mathrm{X}_{1}$ белгісі бойынша ең көп ұшырасқан өлшемдер: 29-30 мм;

$\mathrm{X}_{2}$ белгісі бойынша ең көп ұшырасқан өлшемдер: 27-29 мм;

$\mathrm{X}_{3}$ белгісі бойынша ең көп ұшырасқан өлшемдер: 17,5-18,1 мм;

$\mathrm{X}_{4}$ белгісі бойынша ең көп ұшырасқан өлшемдер: 16-17 мм.

Ақбөкеннің оң аяғына тиесілі асықтардың ішінде $\mathrm{X}_{3}$ белгісіне тән асықтарда бірдей өлшемдер жиі кездесіп отыр (кесте 12).

Кесте 12 - Ақбөкеннің оң аяғына тиесілі асық өлшемдерінің (n=28) вариациялық қатары

Table 12- Variation row of talus bones $(n=28)$ from the right side of the saiga legs

\begin{tabular}{|c|c|}
\hline Латеральды ұзындығы $\left(\mathrm{X}_{1}\right)$ & Кездесу жиілігі (f) \\
\hline 30 & 6 \\
\hline 31 & 6 \\
\hline 30,5 & 4 \\
\hline 32,1 & 2 \\
\hline 32,5 & 2 \\
\hline 31,5 & 2 \\
\hline 34 & 1 \\
\hline 32,9 & 1 \\
\hline 27,6 & 1 \\
\hline 31,1 & 1 \\
\hline 28 & 1 \\
\hline 32 & 1 \\
\hline Медиальды ұзындығы $\left(X_{2}\right)$ & Кездесу жиілігі (f) \\
\hline 28 & 6 \\
\hline 29 & 5 \\
\hline 30 & 5 \\
\hline 27 & 3 \\
\hline 28,5 & 2 \\
\hline 31 & 1 \\
\hline 29,1 & 1 \\
\hline 26,9 & 1 \\
\hline 28,1 & 1 \\
\hline 32 & 1 \\
\hline 28,6 & 1 \\
\hline 26 & 1 \\
\hline Латеральды-медиальды ені ( $\left.\mathrm{X}_{3}\right)$ & Кездесу жиілігі (f) \\
\hline 18 & 9 \\
\hline 18,5 & 4 \\
\hline 17,5 & 3 \\
\hline 19 & 2 \\
\hline 20 & 2 \\
\hline
\end{tabular}




\begin{tabular}{|c|c|}
\hline 18,1 & 2 \\
\hline 17 & 2 \\
\hline 17,1 & 1 \\
\hline 19,5 & 1 \\
\hline 16 & 1 \\
\hline 17,8 & 1 \\
\hline Дорсальды-плантарлы қимасы $\left(\mathrm{X}_{4}\right)$ & Кездесу жиілігі (f) \\
\hline 17 & 7 \\
\hline 16,5 & 4 \\
\hline 19 & 3 \\
\hline 16 & 2 \\
\hline 16,9 & 2 \\
\hline 15,5 & 2 \\
\hline 19,5 & 1 \\
\hline 18 & 1 \\
\hline 17,2 & 1 \\
\hline 18,2 & 1 \\
\hline 16,1 & 1 \\
\hline 17,5 & 1 \\
\hline 18,1 & 1 \\
\hline 18,5 & 1 \\
\hline
\end{tabular}

$\mathrm{X}_{1}$ белгісі бойынша ең көп ұшырасқан өлшемдер: 30-31 мм;

$\mathrm{X}_{2}$ белгісі бойынша ең көп ұшырасқан өлшемдер: 28-30 мм;

$\mathrm{X}_{3}$ белгісі бойынша ең көп ұшырасқан өлшемдер: 18,5-21,8 мм;

$\mathrm{X}_{4}$ белгісі бойынша ең көп ұшырасқан өлшемдер: 16,5-17 мм;

Асықтардың вариациялық қатарын сараптау негізінде ең жиі кездесетін өлшемдердің амплитудасы анықталды:

1. $\mathrm{X}_{1}$ белгісі бойынша ең көп ұшырасқан өлшемдер амплитудасы: 29-32,5 мм (36 асық бойынша).

2. $\mathrm{X}_{2}$ белгісі бойынша ең көп ұшырасқан өлшемдер амплитудасы: 27-30 мм (29 асық бойынша).

3. $\mathrm{X}_{3}$ белгісі бойынша ең көп ұшырасқан өлшемдер амплитудасы: 17,5-21,8 мм (36 асық бойынша).

4. $\mathrm{X}_{4}$ белгісі бойынша ең көп ұшырасқан өлшемдер амплитудасы: 16-19 мм (32 асық бойынша).
Вариациялық қатардан тыс ақбөкен асықтарының көлемі бойынша жалпы амплитудасы келесідей:

1. $X_{1}$ белгісі бойынша ең кіші және үлкен өлшем: 27,9-34 мм;

2. $\mathrm{X}_{2}$ белгісі бойынша ең кіші және үлкен өлшем: 26-31,5 мм;

3. $\mathrm{X}_{3}$ белгісі бойынша ең кіші және үлкен өлшем: 15,5-21,8 мм;

4. $\mathrm{X}_{4}$ белгісі бойынша ең кіші және үлкен өлшем: 15,5-19,5 мм.

Асықтардагы өрнектерге сипаттама

Ақбөкен және қой асығының 6 данасында сызықты белгілер салынған. Орнаменттер асықтың плантарлы (бүк немесе дөңес беті) бөлігіне түскен. Кейбір асықтардағы сызықты өрнектер ортасынан бастап төрт тарапқа тармақталса, енді біреулерінде зигзаг түрінде, торкөз секілді және вертикаль-горизонталь бағыттардағы сызықтардың айқасуымен көрініс тапқан. Бір дана 
ақбөкен және бір дана қой асығының латеральды қырына (алшы жағы) тесік жасалған. Сызықты өрнектер мен тесігі бар асықтардың 6-ы жануардың сол аяғына тиесілі. Қалған екеуі оң аяғына тиесілі.

Асық № 1. Асық ақбөкеннің сол аяғына тиесілі. Өрнек асықтың плантарлы бетіне түскен. Асықтың қақ ортасына диаметрі 1,95×1,93×0,25 мм болатын шұңқыр жасалып, сол шұңқырдан төрт тарапқа 3 сызықтан тармақталады. Сызықтар асықтың шетінен тұйықталады. Жасалу тәсілі қарабайыр, өткір заттың көмегімен түсірілген.

Асық № 2. Асық ақбөкеннің оң аяғына тиесілі. Сызықты өрнектер плантарлы бөлікке түсірілген. Горизонталь және жартылай горизонталь (медиальды бөліктен латеральды бөлікке қарай еңіс орналасқан) бағытта 13 сызық түскен. Вертикаль бағытта 6 сызық горизонталь сызықтарды қиып торкөз жасап орналасқан.

Асық № 3. Асық ақбөкеннің оң аяғына тиесілі. Мұндағы сызықтар № 2 асықтағы сызықтардың көрінісін қайталайды. Бірақ горизонталь бағыттағы сызықтар қатты батырылып жасалса, вертикаль бағыттағы сызықтар әзер көрінеді. Вертикаль бағытта 5 сызық бар. Горизонталь бағытта 9 сызық түскен.

Асық № 4. Асық ақбөкеннің сол аяғына тиесілі. Мұндағы сызықтар № 1-2 асықтағы сызықтарды қайталайды. Бірақ жасалу тәсілі орналасу ерекшеліктері № 2 асыққа қатты жақын. Вертикаль бағытта 5 сызық түссе, горизонталь бағытта 9 сызық түскен.

Асық № 5. Асық ақбөкенге сол аяғына тиесілі. Асықтың плантарлы бетіне түскен сызықтар жоғарыда сипатталған белгілерден біршама ерекше болып келеді. Асықтың плантарлы бетінің медиальды шетіне вертикаль бағытта 1 сызық түсіп, одан латеральды шетіне қарай горизонталь бағытта 4 сызық өткен. Горизонталь сызықтар аздап қиғаш орналасқан.

Асық № 6. Асық ақбөкеннің сол аяғына тиесілі. Плантарлы бөлікке түскен сызықтар жоғарыда аталған бейнелерді қайталамайды. Плантарлы бөліктің медиальды шетіне жақан жерден проксимальды, латеральды шетіне қарай жалпы саны 7 сызық тармақталады. Оның ішінде проксимальды бағытта 4 сызық, медиальды бағытта 2 сызық белгіленген.

Асық № 7. Асық ақбөкеннің сол аяғына тиесілі. Медиальды қырының дорсальды-проксимальды шетінде мұрындық тәріздес тесік жасалған. Тесіктің диаметрі 1,04×0,84 мм құрайды. Үшкір құралдың көмегімен медиальды бетінен плантарлы бетіне қарай тесілген.

Асық № 8. Асық қойдың сол аяғына тиесілі. Медиальды қырының дорсальды-проксимальды шетінде мұрындық тәріздес тесік жасалған. Тесіктің диаметрі 0,16×0,48 мм құрайды. Тесік үшкір құралдың көмегімен медиальды бетінен плантарлы бетіне қарай тесілген (cyp. 6-9).

\section{Археологиялық ұқ̧састықтыар}

Археологиялық зерттеу жұмыстарында ең жиі кездесетін материалдардың ішінде бірінші орында керамикалық бұйымдар болса, екінші жануар сүйектері құрайды. Қолданыста болған сүйектердің ішінде жиі кездесетіні жануардың қабырғалары, асықтары, жауырын және т.б. жануар асықтарының ішінде әрине қой, ешкі және сиыр асығы басымдыққа ие. Үй 


\section{ҚАЗАҚСТАН АРХЕОЛОГИЯСЫ № 4 (6) 2019}

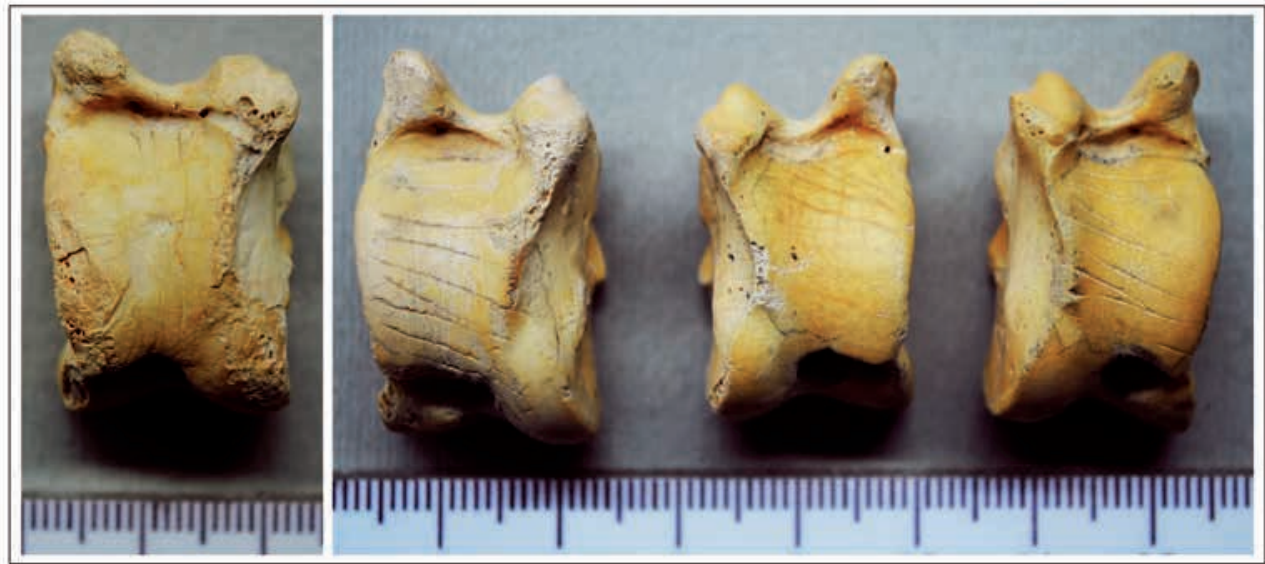

Сур. 6. Бәбіш мола. Өрнекті асықтар. М.С. Шагирбаевтың фотосы

Fig. 6. Babish mola. Ornamented astragals. Photo by M.S. Shagirbayev
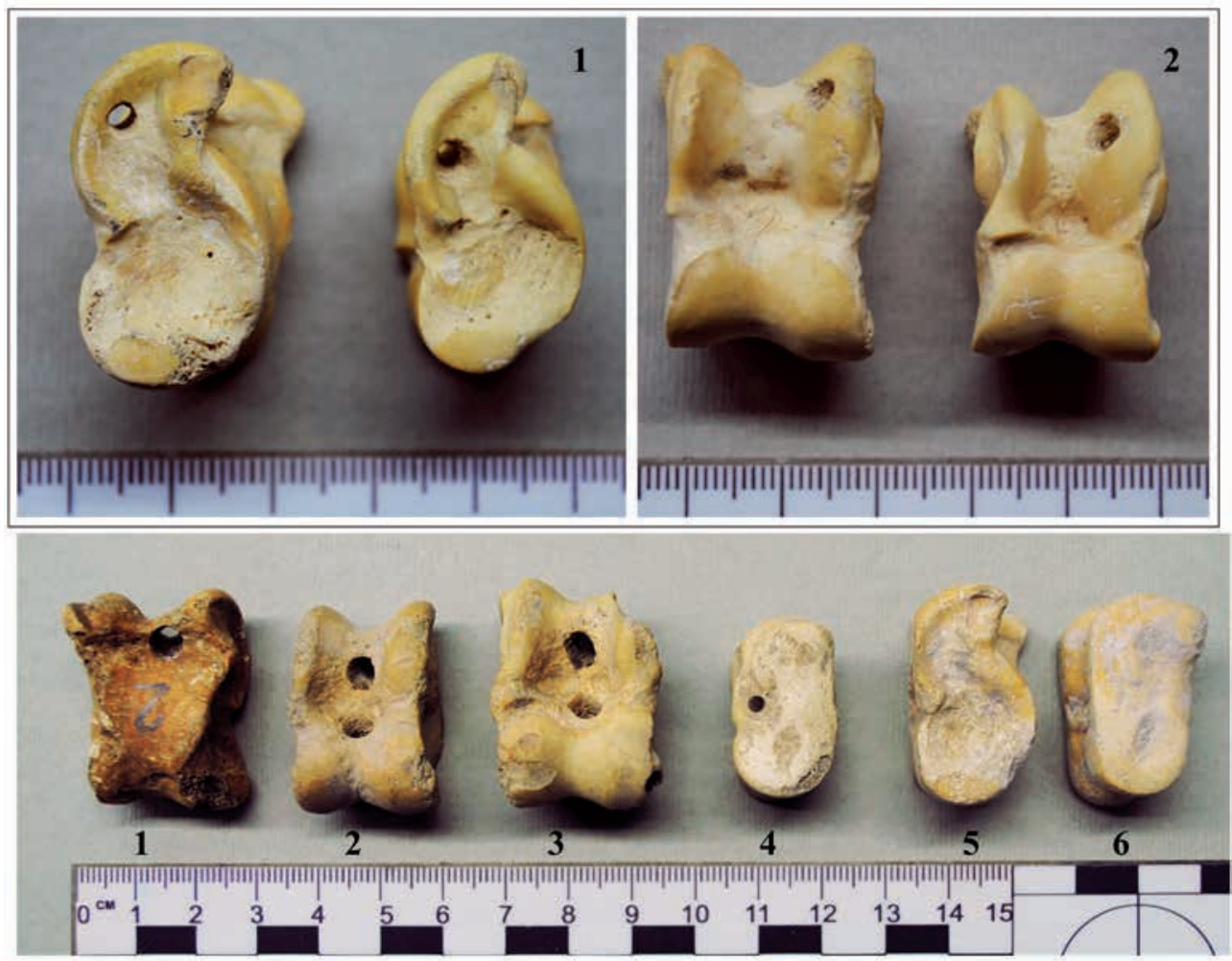

Сур. 7. Үстінцгі қатар: 1, 2-медиальды қырында тесігі бар асықтар (Бәбім мола); Төменгі қатар: 1 - ортавасырлық Ақтөбе (Шардара су қоймасы);

$$
\text { 2-3-Раң; 4-Шарапкент; 5-6-Ақыртас }
$$

Fig. 7. Top row: 1, 2 - astragals with holes at the medial crest; Bottom row: 1 - medieval Aktobe (Chardara reservoir); 2-3-medieval Ran; 4 - Sharapkent; 5-6-Akyrtas 


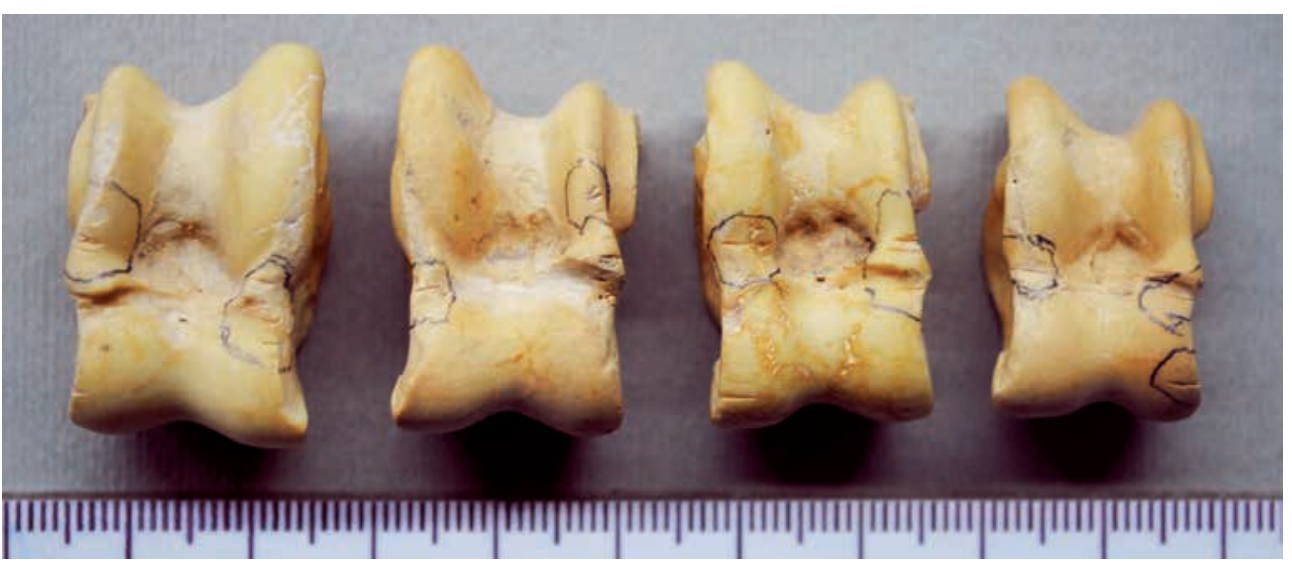

Сур. 8. Антропогендік әсері бар асықтар. М.С. Шагирбаевтың фотосы

Fig. 8. Astragals with anthropogenic influences. Photo by M.S. Shagirbayev

жануарларынан жылқы және түйе асығын кездестіргенімізден, аталған сүйек материалдарда тұрмыстық қолданыста емес, тағам рационында ғана қызмет атқарғанын ескеруіміз қажет. Жабайы жануарлардан сирек жағдайда қасқырдың асықтарын кездестіреміз.Ертежәнеортағасырлық жерлеу орындарында да асықтар топталып немесе жекелеген түрде кездесіп жатады. Қола дәуіріне тән жерлеу орындарынан көбіне қой асықтарымен арқардың кұлжасы және сиыр асығының табылуы да сирек жағдай емес. Зерттеушілер арасындағы жануар асығы туралы тұжырымдар бір жақты емес. Кей жағдайларда асықтың табылуын жерлеу орнындағы мәйіттің жас ерекшелігіне қатысты ойын түрімен, кейде жауынгерлік қызметке қатысты ғұрыптық жоралғылармен де байланыстырады. Жануар асықтарын тас дәуірінен бастап этнографиялық кезеңге дейінгі ескерткіштерден кездестіруге болады.

\section{Орталық}

Қазақстандағы Қарағанды облысы, Жезқазған қаласынан солтүстік-батыста 83 шақырым жерде орналасқан Тоқтауыл палеолиттік тұрағында жүргізілген археологиялық қазба жұмыстары барысында қуысмүйізділер (Bovidae) тұқымдасына тән асықтар табылған. Аталған ескерткішке 2003, 20052008 жылдар аралығында жүргізілген зерттеу жұмыстары барысында қарақұйрық пен ақбөкенге тиесілі остеологиялық материалдар кездессе, соңғы 2008 жылы 1 дана ақбөкен және 1 дана қарақұйрық асығы табылған [Артюхова, 2009, с. 16-17].

Орталық Қазақстандағы Жезқазған өңірінде орналасқан неолиттің соңы және энеолиттің басымен мерзімделетін Шалқия тұрағынан X.А. Алпысбаев бірнеше жануар сүйектерін тауып, оның ішінде қуысмүйізділер (Bovidae) тұқымдасына жататын қарақұйрықтың сүйектерін (асық) анықтаған [Алпысбаев, 1978, с. 117129].

Л.А. Макарова Ботай қонысынан табылған жылқы сүйектерін талдау барысында, қуысмүйізділер (Bovidae) тұқымдасына жататын ақбөкен мен қарақұйрыққа тиесілі сүйектерді анықтаған [Ахинжанов и др., 1992, с. 14]. 

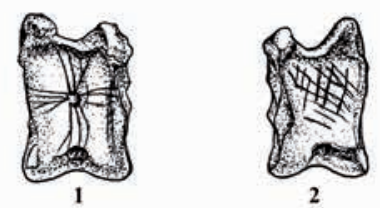

$0 \quad 1$

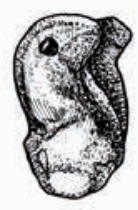

7

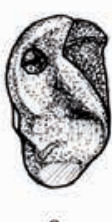

8

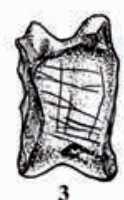

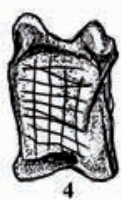
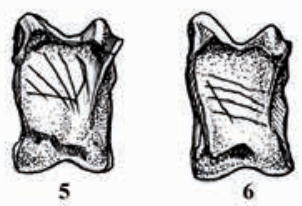

(1)
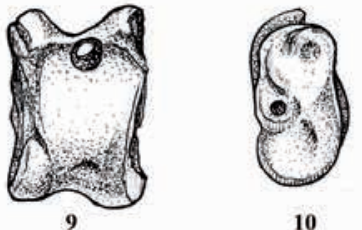

10

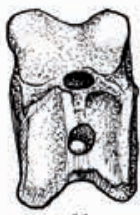

11

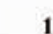

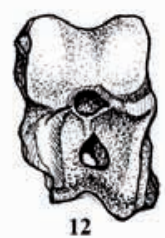

Сур. 9. Жануар асықтарының сызбасы. 1-8 - Бәбіш моладан табылған ақббөкен асықтары; 9 - Opтавасырық Ақттөбе (Шардара су құоймасы); 10 - Шарапкент; 11-12 - ортавасырльқ Раң құаласы

Fig.9. Drawing of animal astragalus. 1-8 - Astragals found from the ancient settlement of Babish Mola; 9 - middle Aktobe (Chardara reservoir); 10 - Sharapkent; 11-12 - medieval castle Ran

Ә.Х. Марғұлан Қарағанды облысы, Шет ауданында орналасқан қола дәуірімен мерзімделетін Бұғылы II қонысына 1956 ж. жүргізген археологиялық қазба жұмыстары барысында ақбөкенге тиесілі 4 дана асық табылғанын айтады. Бірақ асықтардың остеометриялық өлшемдері мен трасологиясы туралы мәліметтер келтірілмеген [Маргулан и др., 1966, с. 219].

Маңғыстау өңіріндегі Бейнеу қаласынан солтүстік-шығыста 140 шақырым жерде орналасқан қола дәуірімен мерзімделетін Тоқсанбай қонысына жүргізілген археологиялық зерттеулер кезінде қуысмүйізділер (Bovidae) тұқымдасына жататын ақбөкен мен қарақұйрықтың сүйектеpi табылған. Жануар сүйектеріне археозоологиялық зерттеу жүргізу барысында ұрықтанудың түрлі сатыларында қалыптасатын шеміршек тәріздес сүйектердің бар екендігі анықталған. Бұл аталған қоныс тұрғындарының аңшылық мерзімін аналық ақбөкендердің буаз болатын кезі деп саналатын күз немесе қыста аулайтынын көрсетеді. Ақбөкендердің Үстірттің солтүстігінен оңтүстікке қарай жүретін миграциясы солтүстік өңірлерде қалың қар түсіп, қорек таусылғанда орын алатындығын ескерсек, археозоологиялық талдау нәтижелерінің дұрыс екендігін байқаймыз [Гайдученко, 2012, c. 160-170].

Үстіртте орналасқан ерте темір дәуірімен мерзімделетін Ақпан ғибадатханасынан басқа да жануарлармен қатар 513 дана ақбөкен және 14 дана қарақұйрықтың сүйектері табылған. Ақбөкен сүйектерінің арасында арнайы шұңқырларға көмілген ақбөкен асықтары ерекше қызығушылық тудырады. Негізінен алғанда № 4 шұңқырда (10 дана), № 8 шұңқырда (6 дана), № 10 шұңқырда 
(12 дана), № 12 шұңқырда (28 дана), № 13 шұңқырда (24 дана) анықталды. Қарақұйрық асықтары аса көп емес, әрі олар басқа сүйектермен аралас орналасқан [Косинцев, Бачура, 2014, с. 320-329]. Остеологиялық материалдарды зерттеушілердің пікірінше ғибадатхана маңайында жануарларды құрбандыққа шалған, оның ішінде жабайы жануарлар белгілі бір ғұрыптың негізінде сойылған. Оның ішінде ақбөкеннің асықтарын жеке айтуға болады. Зерттеушілердің пікірінше асықтар ойынға арналған болуы да мүмкін, яғни ақбөкен асықтары ойынға арналған, ал қарақұйрық (Gazella subgutturosa) асықтары ойынға және бал ашу секілді бір магиялық жосынға арналған. Аталған ғибадатханадағы жалпы сүйектердің 80\%-ы ақбөкен мен құланға тиесілі болып шыққан. Яғни жабайы жануарларды құрбандық ретінде ғибадатхана маңайында сойып, етін жегеннен кейін, сүйектерін арнайы шұңқырларға көмген. Ғибадатханадағы құрбандыққа шалынған малдар негізінен көктемнің соңы және жаз бен күздің басына тура келген.

Қола дәуіріне тән сынташты-петров типіне жататын Большекараганский қорымындағы № 25 обада орналасқан № 13 қабірде жерленген жас баланың қасынан жалпы саны 30 асық табылған. Оның ішінде бірнешеуі ақбөкенге тиесілі. Осы қорымдағы № 16 қабірде жерленген баланың қасынан 50 асық табылған. Оның 2-і ақбөкенге тиесілі [Сотникова, 2015, с. 21-30].

Каменный Амбар 5 қорымындағы № 2 обаның № 4 қабірінде жерленген баланың қасынан 13 асық табылған. Оның ішінде 2-і ақбөкенге тиесілі. № 5 қабірден 147 асық табылған, оның ішінде 27-і ақбөкенге тиесілі. № 11 қабірден 53 асық табылған, оның ішінде 1-і ақбөкенге тиесілі болып шыққан [Сотникова, 2015 , c. 21-30].

Кривое озеро № 3 қорымындағы № 9 обадан 41 дана асық табылған, оның 2-і ақбөкенге тиесілі болып шыққан [Сотникова, 2019, с. 72-84].

1974 ж. Оңтүстік Қазақстанда орналасқан Раң қалажұртына жүргізілген зерттеу жұмыстары барысында бірнеше қой және ақбөкен асықтары табылған. Оның ішінде кейбіреулерінде арнайы тесіктері (дорсальды бетінде, латеральды қырында) және егелген тұстары бар [Жолдасбаев, 1975, с. 28].

Ақбөкен асықтары табылған ескерткіштердің басым бөлігі тас, қола және темір дәуірлерімен мерзімделеді. Ортағасырларда ақбөкен асықтарының кездесуі сиреп, негізінен үй жануарларының асықтарының табылуы жиілейді. Біздің ойымызша ортағасырлардағы жерлеу ғұрыптарында жабайы аңдардың асықтарын қою дәстүрі палеогеографиялық және палеоэкономикалық үдерістерге орай өзінің басымдығын жоғалта бастаған секілді. Сонымен қатар, мал шаруашылығының дамуына байланысты аңшылық кәсіптің жалпы шаруашылыққа шаққандағы үлесі төмендейді. Мұның мысалын кезкелген ортағасырлық ескерткіштерге жүргізілген археологиялық қазба жұмыстары барысында үй жануарына тиесілі асықтардың кездесуінен байқай аламыз.

Ұ.Y. Үмітқалиев 20142015 жылы Шығыс Қазақстан облысы Абай ауданындағы қола дәуірімен мерзімделетін қорымда жүргізілген қазба жұмыстары барысында 140-тан 
астам асықтың табылғанын айтады. Асықтар тас жәшікте жерленген адам мүрдесінің аяқ жағынан кездескен. Асықтардың барлығынан өңіп кетсе де қызыл түсті қынамен боялғаны анық байқалған. Асықтардың сыртқы морфологиялық сипатына қарап, арасында арқардың да асықтары кездесетінін айтады. Ең қызығы көпшілігінің бір шетінен мұрындық тесігі бар болуы. Ұ.Ү. Үмітқалиев асықтардағы мұндай белгілердің болуын уақытында тұмар ретінде тағумен байланысты деген жорамал жасайды. Яғни мәйітті жерлеуге келген туыстары мен жақындарының топырақ салудың орнына осы асықтарды қолданған. Ал тұмар ретінде мойындарында жүрген асықтарын жерлеуге барғанда жібін үзіп қимасына (жақын туысына) берген [Үмітқалиев, 2016, б. 111-116].

Қырғызстандағы Ыстықкөл археологиялық экспедициясы зерттеген Ыстықкөл аймағындағы Кароол-Дёбё (Қарауыл төбе) қорымынан табылған мәйіттің бас жағынан 65 дана қой асығы шыққан [Кольченко, Ротт, 2007, c. 21-34]. Асықтардың 23 данасының бір шетінен (медиальды) тесік жасалса, 28 данасының екінші шетінен (латеральды) тесік жасалған. Кейбіреулерінің плантарлы бетінің бұрышынан тесік жасалған. Кейбір асықтарда екі тесік жасалған. Сегіз асыққа тесік жасалмаған. Бірқатар асықтардың бетінен қызыл түсті бояудың іздері байқалған (сур. 10).

А.П. Липский Минусинск қазаншұңқырындағы Таштық мәдениетімен сәйкестендірілетін жерлеу орынан 51 дана асық тапқан. Ондағы асықтардың бірқатары түрлі сызықтармен көркемделген [Липский, 1956, с. 16-21].

2002 жылы Бөріжар қорымындағы № 2 обада жүргізілген зерттеулер барысында, мәйіттің бас жағынан ішінде 58 асығы бар қыш ыдыс табылған. Кейбір асықтардың қырынан және дорсальды бетінен жасалған тесіктері сақталған. Бұл асықтардың ішінде боялған түрлері кездескен. Тіпті бірқатар асықтар қара-қоңыр және қызыл түспен боялғаны анықталған [Байпаков и др., 2004, с. 180].

С.П. Толстов зерттеген Қой қырылған қала (Кой-КырылганКала) ескерткішін зерттеу барысында жануардың асықтары жиі кездескенін айтады. Мәселен, Н14 бөлмесіндегі шұңқырдан 41 асық табылған. Оның ішінде 6-ның шеті тесілген, 1-нің дорсальды-плантарлы бөлігінен тесілген, кейбіреулерінде тегістеліп, егелген тұстары да бар. Бірқатарының плантарлы бетінде сызықты іздер сақталған. Біреуінде қатар орналасқан сызықты із бар. Н-29 бөлмесіндегі аса үлкен емес шұңқырдан 13 асық табылған. Оның ішінде 2-нің латеральды шетінде тесік бар. С-16 бөлмесінен табылған асықтың плантарлы бетінде тігінен түскен крес ізі бар. Орталық бөлмені айнала қоршаған дәліздің ортаңғы құрылыс кезеңінен екі асық табылған. Оның біреуінің плантарлы бетінде үшкір затпен бес бұрышты жұлдыз тәріздес сызықты із түсірген [Толстов, Вайнберг, 1967, с. 157-158].

Воронеж облысындағы Животин қаласына жүргізілген археологиялық қазба жұмыстары барысында 257 дана жануар асықтары табылған. А.В. Винников қазба барысында жинақталған асықтардың бірқатарындатүрлісызықтықбелгілер мен арнайы тесілген тесіктері бар екендігін айтады (сур. 11). Зерттеуші асықтардың ішінде бидай қалдықтары бар керамикалық ыдыспен бірге табылуына қарап, аграрлық жұмыстарға 
Шагирбаев М.С., Утубаев Ж.Р. Жануар асықтарының археозоологиялық зерттелуі

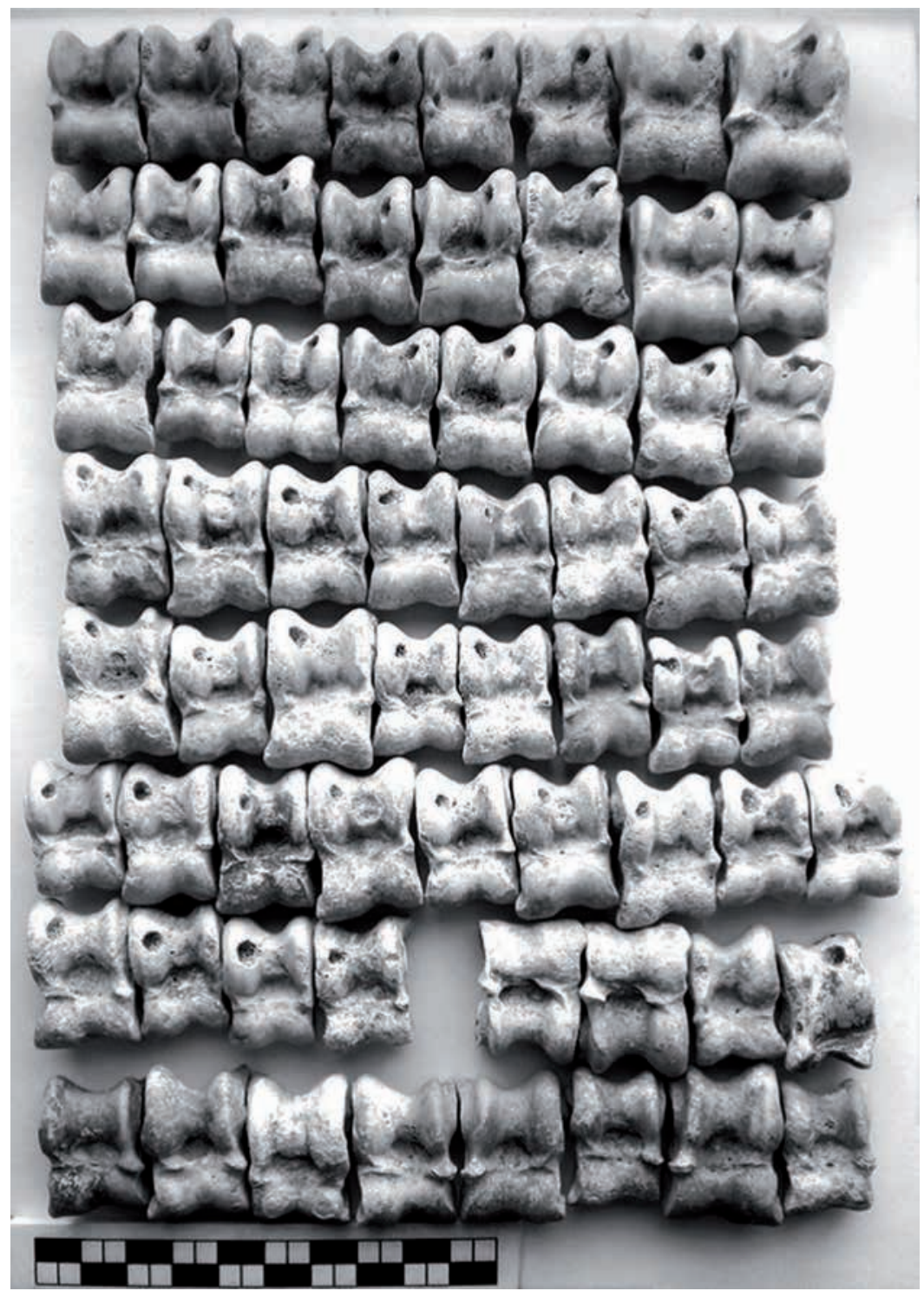

Сур. 10. Кароол-Дёбё ққорымы. Қырвызстан ([Кольченко, Ротт, 2007]: бойынша)

Fig. 10. Burial ground Karool-Döbö. Kyrgyzstan (by: [Kolchenko, Rott, 2007])

арналған ғұрыппен байланыстырған [Винников, 2011, с. 87-94].

2016 жылы Ә.Т. Төлеубаевтың жетекшілігімен Алматы облысы, Алакөл ауданында орналасқан Жайпақ қаласына жүргізілген археологиялық қазба жұмыстары барысында плантарлы бетінде айқыш-ұйқыш сызықтары бар қой асығы табылған [Төлеубаев және т.б., 2016, б. 172-183]. 2014 ж. Алакөл өңіріндегі Қоскеліншек қаласына және 2017 ж. Жайпақ қаласына жүргізілген археологиялық зерттеу барысында жалпы саны 70-ке жуық қой асығы табылған (сур. 12). Оның ішінде 4-нің артқы жағында бетінде тесіктері 


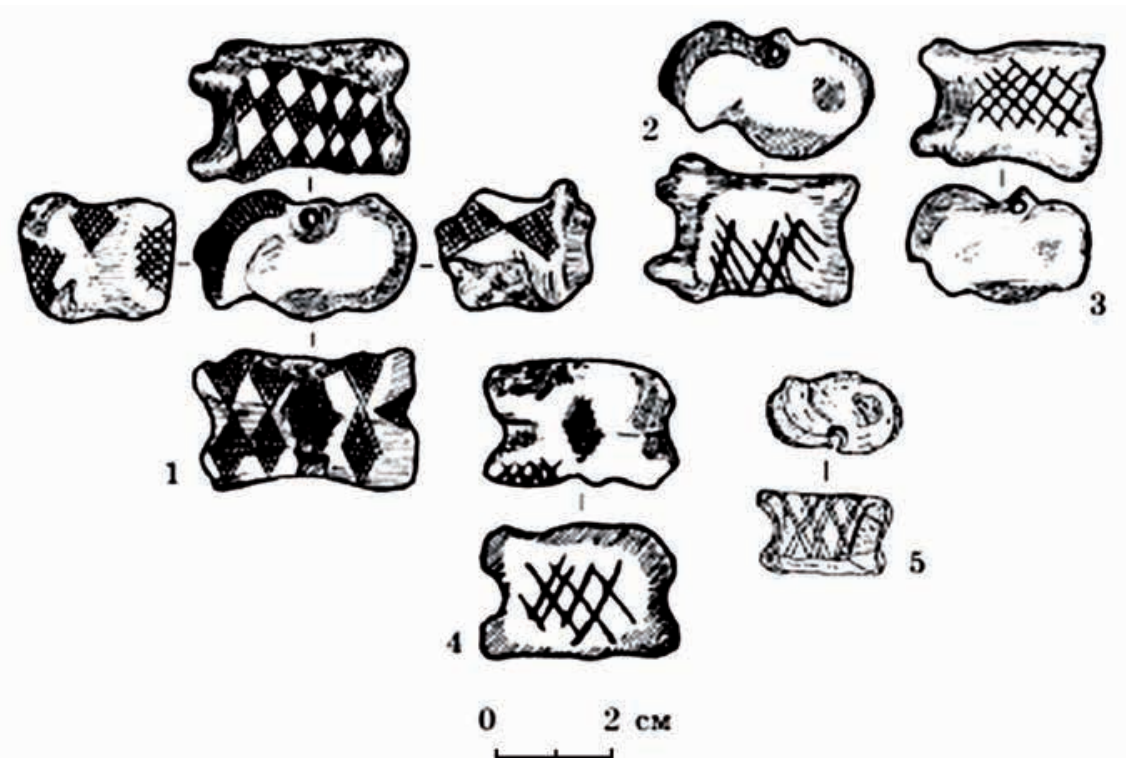

Сур. 11. Животин қ̧аласынан табылван өрнекті асықтар ([Винников, 2011]: бойынша)

Fig. 11. Ornamented Astragalus from Animal Castle (by: [Vinnikov, 2011])

бар (Жайпақ), 6-ның (Жайпақ) медиальды беттері егелген. Аталған ескерткіштен табылған асықтардың ерекшеліктеріне қарап, белгілі бір ойын түріне қолданылған деген тұжырымға келеді [Төлеубаев және т.б., 2018, б. 173-178].

Талғар қаласына жүргізілген археологиялық зерттеулер барысында табылған қой асықтарының ішінде дорсальды-плантарлы бетінен тесіліп өңделген асықтар табылған [Байпаков и др., 2005, с. 100].

Ортағасырлық Қастек қаласына жүргізілген археологиялық зерттеу жұмыстары барысында 36 дана қой асығы шыққан. Оның ішінде 28 данасы сол аяққа тиесілі, 18 оң аяққа тиесілі. Сегіз асықтың сыртынан қоңыр түсті бояу іздері байқалған. Асықтардың ішінде жас жануарға тиесілі түрлері басым болған. Тоғыз асық қайралып, өңделген. [Нуржанов, 2014, c. 462-471].

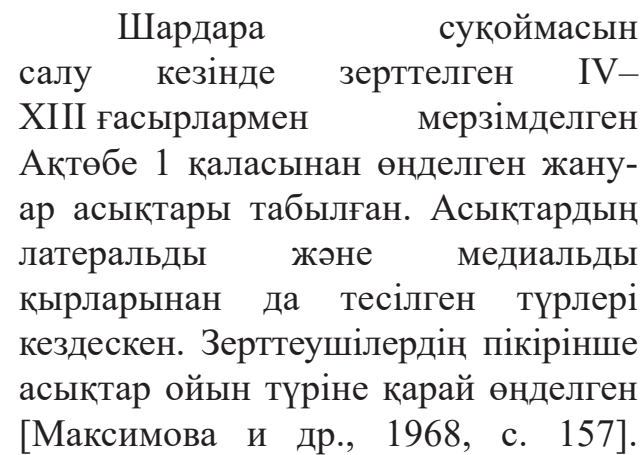
Аталған ескерткіштен табылған өңделген асықтардың археологиялық параллельдері осы аймақтағы ерте кезеңге тән ескерткіштерден де табылған. Мәселен Қауыншы төбе қаласынан табылған асықтардың да латеральды және медиальды қырларында тесіктер болған [Григорьев, 1948]. Қауыншы төбе ескерткішінен табылған әртүрлі өрнекті асықтарды зерттеушілер ойын түрімен байланыстырған.

Шауышқұм төбе қорымындағы № 106 обада анықталған мәйіттің оң 


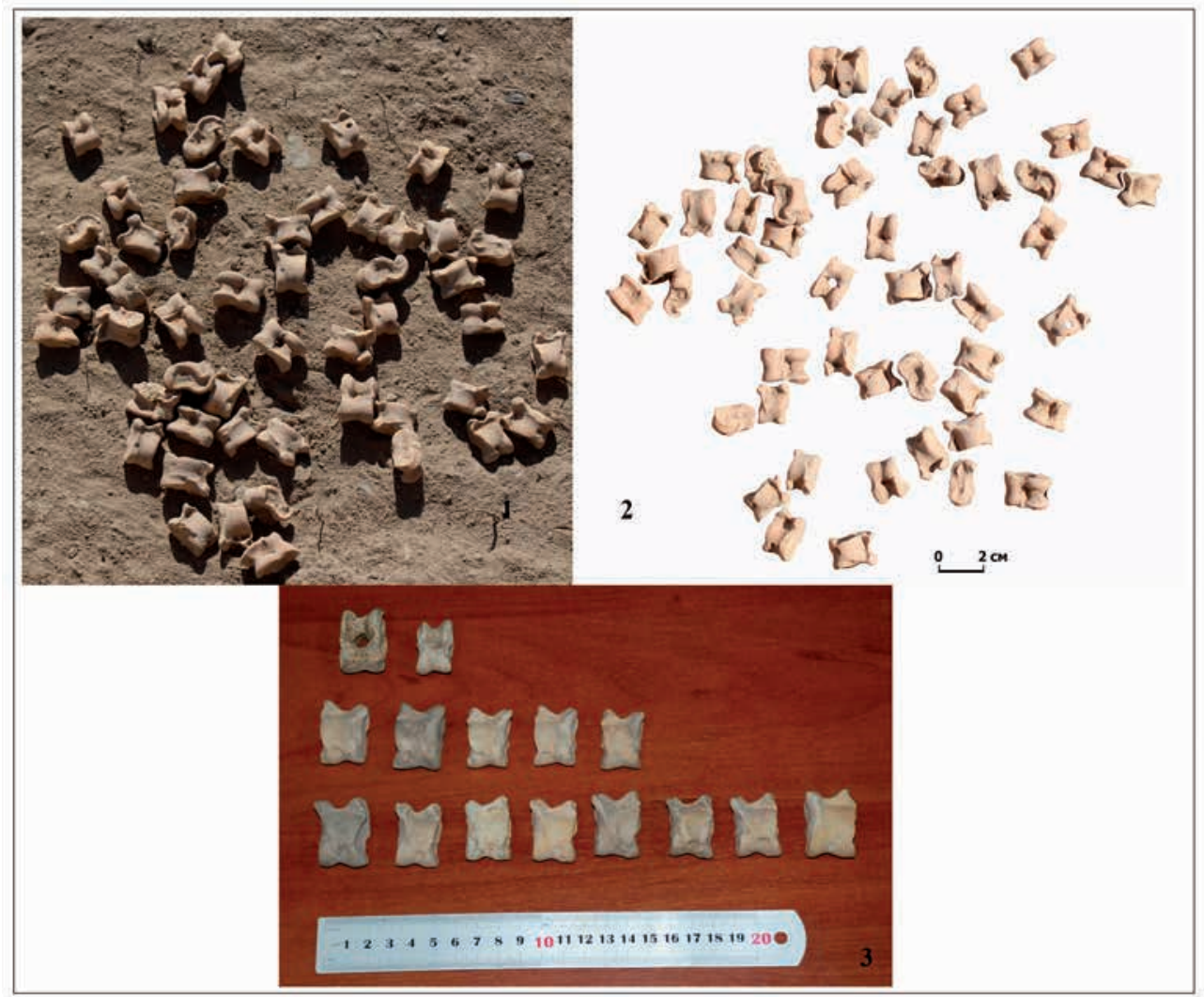

Сур. 12. Алакөл өңіріндегі қ̧алалардан табылван асықтар. 1, 2 - Жайпақ̧ қ̧аласы; 3 - Қоскеліншек құласы. М.С. Шагирбаевтың фотосы

Fig. 12. Astragals found from ancient settlements of Alakul region. 1, 2-Zhaipak; 3 - Koskelinshek. Photo by M.S. Shagirbayev

аяғының тұсынан 32 дана қой асығы және сол аяғының тұсынан 1 дана қой табылған. Бірқатар асықтардың дорсальды беті егеліп, тегістелген. Асықтардың арасында егеліп, қайралған бір дана сиыр және жылқы асығы табылған. Зерттеушілер үлкен жануардың (сиыр мен жылқы) асықтары арнайы сақа ролін атқаруы мүмкін деген тұжырым жасайды [Максимова и др., 1968, с. 259].

Ә.М. Оразбаев Шағалалы қонысына жүргізген археологиялық зерттеу жұмыстары барысында осы Қауыншы төбе ескерткішінен табылған асықтардағы өрнектерге ұқсас асықтар жиынтығын тапқан [Оразбаев, 1965].
Ташкент маңындағы Пскент қорымындағы бір жерлеу орынан 62 дана уақ малдың асығы шыққан [Кожомбердиев, 1963, с. 72]. Бірақ аталған материалдардың жекелеген элементтердің нақты сипаттамасы жасалмаған.

Жануар асықтарына қ̧атыстыь тұжырылдар

С.В. Сотникова қола дәуіріне тән ескерткіштердің ішінде жас балалар жерленген қабір шұңқырынан табылған асықтарды саралап, асықпен көму дәстүрін баланың жас ерекшелігіне қарай бөлінетінін айтады [Сотникова, 2015, с. 2130]. С.В. Сотникованың пікірінше жоғарыда аталған мәдениеттерге тән 
қоғамдағы жасөспірім ер балалар асық ойыны пішініндегі жорамалдау немесе болжау ғұрыптары арқылы сакральды әлеммен арада байланыс түзуші ерекше бір әлеуметтік топты құраған [Сотникова, 2014, с. 26-34].

С.П. Толстов асықтардың табылуын ежелгі ойын түрлеріне, ғұрыптық жосындармен байланыстырады. Асықтар бүгінде ұмыт болған, бірақ уақытында маңызды белгілі бір ойын түрлерінде қызмет атқарған болуы мүмкін. Сонымен қатар тесігі бар (латеральды немесе медиальды қырындағы тесіктер) асықтар бәле-жаладан қорғаушы тұмар қызметін де атқарған боулы мүмкін [Толстов, Вайнберг, 1967, c. 157-158].

А.Ә. Нұржанов асықтардың латеральды немесе медиальды қырларының егелуін және дорсальды бөлігіне жасалған тесіктерді қазақтың дәстүрлі «асық ойындарымен» байланыстырады [Нуржанов, 2014, c. 462-471].

И.Ф. Ковалева асықтардың жерлеу орындарынан табылу мәселесіне қатысты ғылыми пікірін білдірген. Ғалымның ойынша асықтар қола дәуірінің қима мәдениетіне тән ескерткіштерде ойынға арналған зат ретінде қарастырумен қатар, кейінгі кезеңдерінде белгілі бір балгерлік жорамал жасауға пайдаланған. Яғни И.Ф. Ковалеваның ойынша асықпен бірге жерленген мәйіт «ғұрып пен оны сақтаушы абыздар секілді кәсіби балгерлер» ұғымына сәйкес болады [Ковалева, 1990, с. 59-71].

Жалпы жерлеу орындарындағы асықпен жерлеу ғұрыптарының болжау, жорамалдау ғұрыптарымен В.Н. Зудина [1998], Е.Е. Антипина., B.C. Ольховский [Антипина, Ольховский, 2000, с. 79-88], С.А. Ворошилова [2008, с. 157-159],
Л.Л. Гайдученко [2011, с. 360-365], О.М. Грищук [2013, с. 24-34] секілді зерттеушілер де байланыстырған.

В.А. Кольченко және Ф.Г. Ротт Қырғызстанда орналасқан КароолДёбё қорымындағы № 7 обадан табылған асықтардың қырларындағы тесіктер жіпке тізіп байланып, мәйіттің басына тағылған деген пікірді алға тартады. Яғни жерленген адам тірі уақытында ойнаған асықтарын өзімен бірге жерлеген болуы мүмкін [Кольченко, Ротт, 2007, с. 21-34].

А.П. Липский жерлеу орындарынан табылған асықтардың этнографиялық параллельдерін хакастардың этно-дәстүрлерінен іздейді. Хакас халықтарында қой асықтары осы жануардың жанын қорғаушы ретінде танылған. Хакас халықтарының «хазых оин» атты дәстүрлі асық ойынында, жеңілген адам асықтарды сатып алуы тиіс. Бұл жеңілген адамның отарындағы қой санының ұтылған асық санымен бірге жоғалу мүмкіндігін тоқтатадымыс. Егер жеңілген адам асықтарды қайта сатып алмаса, жеңген адам ұтқан асықтарды қораның бұрышына апарып: «менің қорамда сақталыңдар, менің отарымда көбейіңдер» деген сөздерді айтып, көміп тастайтын болған [Липский, 1956, с. 22-24].

Хакас халықтарының ішіндегі этнографиялық топ саналатын Сaғайлықтарда қой мен ешкі асықтарын тастамай жинап отыратын болған. Асық саны 100-ден асқанда барлығын мал қораның бұрышына апарып көмген. Бұл өлген жануарлар қайта туылып, көбейсін деген ұғыммен байланысты жасалатын жосын болып табылады [Липский, 1956, с. 22-24].

Хакас халықтарының ішіндегі этнографиялық топ саналатын Качинастарда (Качинцы) қой асықтарын құмырсқаның илеуіне тастаған. Бұл 
да қойдың құмырсқадай қаптап, көбею ұғымымен астасады [Липский, 1956 , с. 22-24].

Сағайлықтарда сақа ретінде саналатын асықта оның қожайынының таңбасы салынатын болған. Асық ойыны кезінде асықтың иесі өзінің таңбасы салынған сақаны ұтқызбауға тырысады. Егер ұтқызып алған жағдайда, отарындағы қойдың азайып кету қапуі төнеді. Ең қызығы асық ойыны кезінде ұтылған ойыншыға ешкім асық бермейді. Егер асықты берген жағдайда отарына зиян тиедіміс [Липский, 1956, с. 22-24].

А.И. Юдиннің тарапынан асықпен жерлеуге қатысты қызықты талдау жасалған. Оның ойынша ешқандай сызықтық белгілері мен өрнектері жоқ асықтар «ешқандай ғұрыптық мақсатта пайдаланылмаған, тек асықпен байланысты белгілі бір ойынға арналған», ал бетінде бедері немесе сызықты өрнектері бар асықтар жерленген адамның белгілі бір әлеуметтік мәртебесін білдіреді (мүмкін ғұрыптық қызмет атқарушы) [Юдин, 2009, с. 146-170].

В.В. Цимиданов Төменгі Волга аймағындағы бірнеше қорымдардан табылған асықтарды талдау барысында төмендегі мағлұматтарды анықтайды:

1) кейінгі қола дәуірінде Төменгі Волга аймағында асықпен жерлену көбіне жас жеткіншектер мен балалардың жерлеу орындарынан табылған;

2) аталған аймақтағы қима мәдениетіне тән жерлеу орындарындағы асықпен (бес немесе одан да көп асық) бірге жерлеу ғұрпының барлығы дерлік балалар немесе жеткіншектерге тиесілі;

3) асықпен бірге жерленген бала немесе жеткіншекке тиесілі обалар басқа да қатардағы обалардан ішкіқұрылымы мен сыртқы пішіні бойынша, асықтан басқа ешқандай айырмашылығы болмаған.

4) асықпен жерленген ғұрыптарда кей жағдайларда қосымша заттар анықталған. Оның ішінде ойынға қатысты жылқы топайлары, тістері, ipi қара асығы және т.б. қыш немесе тастан жасалған заттар [Цимиданов, 2015, c. 56-69].

Жалпы жерлеу орындарынан табылатын асықтар оның ішінде уақ малға тиесілі асықтар тек ойын түріне ғана арналмаған, сонымен қатар басқа да ғұрыптық іс-шаралар шеңберіне қатысты болатыны жөнінде этнографиялық мәліметтерді кездестіре аламыз. Мәселен иран халықтарында асықтар әйелдер босану кезінде, жаман күштерді қуу ғұрыптарында қолданатын болған [Цимиданов, 2001, с. 215-248]. Осы мәселе жөнінде В.А. Подобед, А.Н. Усачук және В.В. Цимидановтар көне дәуірде жануар асықтары адамды о дүниемен байланыстырушы құрал ретінде пайдалануы мүмкін екендігін алға тартады [Подобед и др., 2013, c. 56-72].

А.И. Юдин жерлеу орындарындағы асықтардың кездесуінің екі түрін негіздейді [Юдин, 2009, c. 146-170]. Біріншісі үлкен адамдардың қасына қойылған ақыреттік заттарда асықтың кездесуі және жас балалардың қасынан асықтардың кездесуі. Әрине үлкен кісілердің жанына асықтың кездесуі бұл бізге белгісіз діни ғұрыптық жағдаймен байанысты болатыны анық. Ал жас балалардың қасынан асықтың кездесуін бірыңғай ойын түріне жатқызу өз кезегінде қателікке ұрындыруы да мүмкін секілді. Әрине асықтың жас балалар үшін ойын мақсатында қолданыс табатынын жоққа шығара алмаймыз. 
Бірақ, осы мәселе жөнінде М. Бойс және Р.Б. Пандей секілді ғалымдар басқа бір тұжырымдарын мысалға келтіреді [Бойс, 1987, с. 27]. Бұл жерде біз асықпен жерленген балалардың жас мөлшерінің ортақ бөлімін шығаратын болсақ, шамамен 6-14 жас аралығындағы балалардың мүрдесінде жануар асықтары жиі кездеседі. Көне дәуірдегі халықтарда осы жастағы балалар арнайы бағыштау (инициация) ғұрпынан өтетіні белгілі. Мұндай ғұрыптар көне сақ тайпаларында кездеседі [Акишев, 1984, с. 113]. Кей жағдайда талған ғұрып бірнеше жылға дейін жалғасын табады [Бойс, 1987, с. 27]. Яғни инициация ғұрпындағы адам екі дүние арасындағы немесе өлі мен тірі арасындағы деп есептеледі. Мұндай ғұрып-жоралғыларды әлемнің әр түкпіріндегі халықтардан кездестіре аламыз [Пропп, 1986, с. 93-101].

Сонымен жасөспірім балалардың жанына қойылатын ақыреттік заттардың қатарынан асықтардың кездесуі, өз кезегінде балалардың белгілі бір ғұрыптық жосындарда екі дүние арасындағы кезеңі немесе екі әлемді байланыстырушы қызметін атқаруы мүмкін екендігін жоққа шығармаймыз. Осы жағдайға сәйкес B.А. Лопатиннің пікірі ерекше қызығушылық тудырады. Оның ойынша жасөспірім балалар қайтыс болған жағдайда, олардың жанын о дүниеге аттандырарда трансферлік қарымқатынас жасауға негіздеп, белгілі бір жолдау, бағыштау заттарын бірге жерлеуі мүмкін [Лопатин, 2010, с. 125-129]. Жоғарыда атап өткендей, асықпен бірге жерленген обалардың басқа да қатардағы обалардан ішкі құрылымы мен сыртқы пішіні бойынша ешқандай ерекшелігі жоқ болғанымен, онда жерленген мәйіттің жоғарғы дәрежеге жетпегенін, соған жетер жолда қайтыс болуымен байланысты. Бұл әрине ақыреттік заттардың ішінде асықтың көбіне жасөсіпірім балалардың жанынан табылумен көрініс табады. Асықтардың бетіндегі белгілі бір сызықты өрнектер мен белгілердің кездесуі туралы әлі күнге дейін ғылымда ортақ пікір жоқ. В.В. Цимидановтың зерттеулерінде сызықты белгісі бар асықтар жаратушыға немесе ата-баба рухына бағытталған сызбалар іспетес болуы да мүмкін немесе қандай жануардың асығы қойылса, сол жануардың молшылығын тілеуі де болуы мүмкін деген пікір кездеседі [Цимиданов, 2015, с. 65]. А.С. Липский Хакастарда асықтың иесі өзінің таңбасын (мүмкін әулеттің таңбасы?) өзіне тиесілі асықтардың сақасына енгізетінін айтады. Бұл іс-әрекеттің де түпкі мағынасы отардағы қоймен байланысты. Белгісі бар асықты жоғалтқан жағдайда, отардағы қойға да зиян тиюі мүмкін [Липский, 1956, c. 22-24].

\section{Қорытынынды}

Куысмүйізділер

(Bovidae)

тұқымдасына жататын жануарлардың остеологиялық материалдары сарапталған археозоологиялық мәліметтер отандық археологияда аса көп қарастырылмаған мәселелердің бірі. Оның үстіне археологиялық қазба жұмыстары барысында көбіне үй жануарларына тиесілі материалдар ұшырасады. Ал ақбөкен, қарақұйырық секілді жануар сүйектері қазба барысында бірен-саран ғана кездесетіндіктен, арнайы зерттеу нысанына айналмаған. Сонымен қатар, тек ақбөкен асығының 80-ге жуық данасының бір жерден табылуы да бірінші рет кездесіп отыр. Қазақстан территориясындағы ескерткіштерден табылған жануар сүйектеріне қа- 
тысты археозоологиялық мәліметтер жыл сайын сирек те болса жарияланып, ғылыми айналымға еніп келе жатқанымен, жануар сүйектерінің ішінде асыққа қатысты, оның морфометриялық өлшемдеріне қатысты мәліметтер жоқтың қасы. Асықтарды жоғарыда аталған 4 белгі бойынша морфометриялық талдау барысында келесі нәтижелерге қол жеткізілді:

- Асықтардыңаталғантөртбелгі бойынша өлшемдері анықталды;

- Әрбір белгінің ортақ өлшемдері шығарылды;

- Ортақ арифметикалық

мөлшері анықталды;

- Орта квадраттық мағынасы анықталды;

- Орта

квадраттық

ауытқушылығы анықталды;

- Орта арифметикалық қателігі анықталды;

- Әрбір белгідегі өлшем

бірліктердің вариациялық қатары шығарылды.

Біздің ойымызша, аталған зерттеу нәтижелері нақты бір ғылыми жаңалық әкелмегенімен, отандық археозоология ғылымында қуысмүйізділер (Bovidae) тұқымдасына жататын асықтардың биометриялық өлшемдері туралы мәліметтер базасын толықтырары сөзсіз. Оның үстіне куысмүйізділер (Bovidae) тұқымдасына жататын жануарлардың асықтары бір-бірінен оңай ажыратылмайтыны белгілі. Осы мәселелерді шешуде жоғарыда жүргізілген биометриялдық зерттеу нәтижелері көмекші құрал бола алады.

Қазба барысында жануар асықтары жиі кездескенімен, нақты ақбөкен асықтарының шоғырланып кездесуі кездейсоқ емес. Асыққа қатысты археологиялық параллельдерді талдау барысында, асықтың топталып кездесуінің семантикасы жөнінде ғылыми көзқарастар да бір жақты емес екендігіне көз жеткіздік. Нақты Бәбіш Мола қаласынан табылған ақбөкен асықтары сол кезеңдегі ғұрыптық жосындарға қатысты жинақталған тәрізді. Себебі ақбөкен асықтары үй жануарларының асықтары секілді оңай қолға түспейтіні анық. Бұл жануарды аулау да өз алдына үлкен мәселе. Көне заманда жылдам әрі секемшіл жануарды топтап қолға түсіру оңай шаруа болмағаны белгілі. Біздің тарапымыздан зерттелген асықтар әртүрлі жастағы ақбөкенге тиесілі болғанымен, негізінен орта жастағы ақбөкеннің асықтары басым екендігін көрсетеді. Кәрі жануарға тиесілі асықтар бірлі-жарым ғана. Бұл өз кезегінде аталған жануарлардың аулануы мерзімі де белгілі бір уақытқа негізделгенін көрсетеді. Бәбіш Мола қаласының сол кезеңдегі тұрғындарының діни және тұрмыстық ғұрып-жосындарында асықтың өзіндік орны бар екендігін көреміз. Оның ішінде ақбөкен асықтарының шоғырланып кездесуі, аталған жануардың да салттық жоралғыларда ерекше рол атқарғанын байқауға болады. Мұны әлі күнге дейін халық арасында ақбөкен мүйіздерін үйдің кіре-беріс маңдайшасына іліп қоюынан да көруге болады. Жалпы қазақ этнографиясында жабайы жануар сүйектері белгілі бір күшке ие, «жаман рухтарды қуушы» деген түсінік бар екендігін жоққа шығаруға болмайды. Әрине ақбөкен асықтарын ойынға пайдаланбаған деуге болмайды. Бірақ аталған жануарға тиесілі асықтар, жалпы асықпен байланысты ойындардың барлығына жарай бермеуі де мүмкін. Себебі ақбөкен асығының көлемі 
кіші, жұмырланған, қолға аздап икемсіздеу. Егер асықты дәлдеу, иіру ойындары болса, аталған жануар асығы тиімсіз. Мұндай ойындарға қой, арқардың құлжасы, кейбір ойын түріне қарай сиыр асықтары өте тиімді болып табылады. Қой асықтарын кейде егеп, тегістеп, тесіп ауыр қорғасын құюы да осы ойын түрлерімен байланысты. Ал ақбөкен асықтарына мұндай трасологиялық әсер ету, ойын барысында көп ыңғайсыздық туғызады. Асықтардың бетіне салынған түрлі сызықтар мен геометриялық өрнектерде де белгілі бір идеологиялық мағына бар секілді. Біздің ойымызша асықтың бетіндегі сызықтар оның иесінің таңбасымен байланысты болуы мүмкін. Ақбөкен асықтарының қырына түсірілген тесіктер оларды жіпке тізіп, байлау әрекетімен байланысты. Жоғарыда келтірілген археологиялық мысалдардан көріп отырғанымыздай, мұндай тесіктер (бұл жерде асықтың латеральды және медиальды қыры сөз болып отыр - Ш.М.) көп жағдайда ғұрыптық жосындарға байланысты жасалады. Сонымен, жоғарыда келтірілген мәліметтерді сараптай келе, Бәбіш Мола қаласынан табылған ақбөкен асықтары сол жануармен байланысты ғұрыптық жосындарға байланысты жиналып, сақталған деген тұжырым жасаймыз.

\section{ӘДЕБИЕТ}

1. Акишев А.К. Искусство и мифология саков. Алма-Ата: Наука, 1984. 176 с.

2. Алпысбаев X.A. О находках индустрии каменного века в Каржантау и Караоба // Археологические памятники Казахстана. Алма-Ата: Наука, 1978. 214 с.

3. Антипина E.E., Ольховский В.С. Археозоологические материалы из главной культовой конструкции святилища Байте III // Археология, палеоэкология и палеодемография Евразии. Москва: Геос, 2000. С. 79-88.

4. Артюхова O.A. Отчет о полевых исследованиях. Токтаульский отряд Цетрально-Казахстанской археологической экспедиции в 2008 г. // Архив Института археологии им. А.Х. Маргулана, д. 2895.

5. Ахинжанов С.М., Макарова Л.А., Нурумов Т.Н. К истории скотоводства и охоты в Казахстане (по остеологическому материалу из археологических памятников энеолита и бронзы). Алматы: «Гылым», 1992. 218 с.

6. Байпаков К.М., Воякин Д.А., Ержигитова А.А., Савельева Т.В., Шарденова 3.Ж., Ахатов Г.А., Шербаев Р.К. Работы Южно-Казахстанской комплексной археологической экспедиции // Новые исследования по археологии Казахстана: тр. науч.-практ. конф. «Маргулановские чтения-15». Алматы: Институт археологии им. А.Х. Маргулана, 2004. С. 169-193.

7. Байпаков К.М., Савельева Т.В., Чанг К. Средневековые города и поселения Северо-восточного Жетысу. Алматы: Credo, 2005. 188 с.

8. Бойс М. Зороастрийцы. Верования и обычаи. М.: Наука, 1987. 304 с.

9. Винников А.3. Костяные амулеты со славянского Животинного городища VIII - начало ХІ века // Вестник ВГУ. Сер.: история, политология и социология. 2011. № 1. C. 87-94.

10. Ворошилова С.А. Астрагалы - особый элемент детского погребального обряда (по материалам могильника Бестамак) // XL Международная Урало-Поволжская археологическая студенческая конференция. Самара: Изд-во Самар. ун-та, 2008. C. $157-159$.

11. Гайдученко Л.Л. Особенности сложения жертвенного комплекса ямы № 170 могильника Бестамак // Тәуелсіздіқ кезеңіндегі Қазақстан археологиясы: қорытындылары мен келешегі. Алматы: Ә.Х. Марғұлан атындағы Археология институты, 2011. Т. І. С. 360-365. 
12. Гайдученко Л.Л. Остеологический комплекс поселения Токсанбай // Труды филиала Института археологии им. А.Х. Маргулана в г. Астана. Астана: Изд. гр. ФИА им. А.Х. Маргулана в г. Астана, 2012. Т. І. С. 160-170.

13. Григорьев Г.В. Келесская степь в археологическом отношении // СА. 1948. № 1. C. 53-68.

14. Грищук O.M. Астрагали як елемент поховального обряду населення дніпродонської бабинської культури // Донецький археологічний збірник. № 17. Донецк: ДонНУ, 2013. С. 24-34.

15. Громова В. Определитель млекопитающих СССР по костям скелета. М.: изд-во АН СССР, 1960. Вып. 2. $121 \mathrm{c.}$

16. Жолдасбаев С. Раскопки «Ран» 1974-1975 гг. Полевой дневник // Архив ИИАЭ АН КазССР. Ф. 11, оп. 2, д. 92, 45 с.

17. Зудина В.Н. Археологические древности Южного Средневолжья. Самара: Самарский университет, 1998. 124 с.

18. Ковалева И.Ф. Срубные погребения с наборами альчиков // Исследования по археологии Поднепровья. Днепропетровск: Изд-во Днепр. ун-та, 1990. С. 59-71.

19. Кожомбердиев И. Катакомбные памятники Таласской долины // Археологические памятники Таласской долины. Фрунзе: Елим, 1963. С. 33-79.

20. Кольченко В.А., Ротт Ф.Г. Аварийные работы на могильнике Кароол-Дёбё в 2003 г. // Материалы и исследования по археологии Кыргызстана. Бишкек: «Илим», 2007. Вып. 2. С. 21-34.

21. Косинцев П.А., Бачура О.П. Фауна млекопитающих из святилища Акпан на Устюрте // Труды филиала Института археологии им. А.Х. Маргулана в г. Астана. Всадники Великой степи: традиции и новации. Астана: издат. гр. ФИА им. А.Х. Маргулана в г. Астана, 2014. С. 320-329.

22. Курманкулов Ж., Утубаев Ж.Р. Античные памятники нижней Сырдарьи // Электронный научный журнал «edu.e-history.kz». 2019. № 2. URL: http://edu.e-history. $\mathrm{kz} / \mathrm{ru} /$ publications/view/268 (дата обращения 04.10.2019 г.).

23. Липский А.Н. Некоторые вопросы Таштыкской культуры в свете сибирской этнографии // Краеведческий сборник. № 1. Абакан: Хакасское книжн. изд-во, 1956. C. $16-24$.

24. Лопатин B.A. Смеловский могильник: модель локального культурогенеза в степном Заволжье (середина II тыс. до н.э.). Саратов: Наука, 2010. 244 с.

25. Маргулан А.Х., Акишев К.А., Кадырбаев М.К., Оразбаев А.М. Древняя культура Центрального Казахстана. Алма-Ата: Наука, 1966. 436 с.: ил.

26. Максимова А.Г., Мерщиев М.С., Вайнберг Б.И., Левина Л.М. Древности Чардары (Археологические исследования в зоне Чардаринского водохранилища). АлмаАта: изд-во «Наука» КазССР, 1968. 271 с.

27. Нуржанов А.А. Некоторые результаты палеозоологических и палеоботанических исследований на городище Кастек // «Марғұлан оқулары - 2014»: академик Ә.Х. Марғұланның 110-жылдығына арналған халықар. ғыл.-практ. конф. матер. Алматы; Павлодар: Павлодар Мемлекеттік педагогика институты, 2014. С. 462-472.

28. Подобед B.A., Усачук А.Н., Цимиданов В.В. Зубы человека в обрядах племен Поволжья эпохи бронзы // Поволжская археология. 2013. № 3 (5). С. 56-72.

29. Пропn В.Я. Исторические корни волшебной сказки. Л.: Изд-во ЛГУ, 1986. $366 \mathrm{c}$.

30. Сотникова С.В. Воинские погребения эпохи поздней бронзы с наборами астрагалов: проблема интерпретации // Поволжская археология. 2019. № 1 (27). C. $72-84$.

31. Сотникова C.B. Детские погребения с наборами альчиков и роль игры в обществах степного населения эпохи бронзы // ВААЭ. 2014. № 2 (25). С. 26 -34.

32. Сотникова C.B. Детские погребения с наборами астрагалов как отражение половозрастной стратификации в обществах эпохи бронзы на территории евразийских степей (по материалам памятников синташтинско-петровского, потаповского, 
покровского типов) // Вестник Пермского университета. Сер. История. 2015. Вып. 1 (28). C. $21-30$.

33. Толстов С.П., Вайнберг Б.И. Койкрылган-кала памятник культуры древнего Хорезма IV в. до н.э. - IV в. н.э. М.: Наука, 1967. 350 с.

34. Толстов С.П., Воробьева М.Г., Раппопорт Ю.А. Работы Хорезмской археолого-этнографической экспедиции в 1957. // Полевые исследования Хорезмской экспедиции в 1957 году. МХЭ, Вып. 4. М.: Изд-во восточной литературы, 1960. C. 3-63.

35. Төлеубаев Ә.Т., Жұматаев Р.С., Шавырбаев М.С. Ортағасырлық Жайпақ қаласына 2016 жылы жүргізілген қазба жұмыстарының кейбір қорытындылары // Археологиядағы зерттеудің жаңа әдістері: Қазақстан Республикасы тәуелсіздігінің 25 жылдығына арналған «Халық - тарих толқынында» мемлекеттік бағдарламасы аясындағы халықар. ғыл.-тәж. конф. матер. (Алматы, 30 қараша 2016 ж.). / Жауапты ред. Ғ.Т. Бексеитов. Алматы: Қазақ университеті, 2016. 172-183-бб.

36. Төлеубаев Ә.Т., Жұматаев Р.С., Шакенов С.Т., Ервабылов А.Е., Шагирбаев М.C. Ортағасырлық Жайпақ I қаласына 2017 жылы жүргізілген археологиялық зерттеудің кейбір қорытындылары // Қазақстан мен іргелес елдердің тарихи-мәдени мұрасын зерттеудегі заманауи әдістер мен тұрғылар: халықар. ғыл.-әдіст. конф. матер. («IX Оразбаев оқулары») / Жауапты ред. Ғ.Қ. Омаров. Алматы: Қазақ университеті, 2018. 173-178-бб.

37. Үмітқалиев Ұ.Y. Асық баланың ойыны емес - бабаның мұрасы // Қазақстанның тарихи-мәдени мұраларының өзекті мәселелері: өткені, бүгіні мен болашағы: тарих ғыл. докторы, профессоры Мадияр Елеуовтың 70 жылдық мерейтойына арналған халықар. ғыл.-тәж. конф. матер. (Алматы, 6 мамыр 2016 ж.). / Жауапты ред. А.Б. Қалыш. Алматы: Қазақ университеті, 2016. І-бөлім. 111-116-бб.

38. Цимиданов B.B. Астрагалы в погребениях степных культур эпохи поздней бронзы и раннего железа // Археологический альманах. № 10. Донецк: «Лебедь», 2001. C. $215-248$.

39. Цимиданов В.В. Погребения срубной культуры с астрагалами из Новопокровки-2 (Нижнее Поволжье): «игроки» или медиаторы? // ТПАИ. 2015. № 1 (11). C. 56-69.

40. Юдин А.И. Погребения с астрагалами из Новопокровки-ІІ: служители культа или «игроки»? // Археология Восточно-Европейской степи. 2009. Вып. 7. С. 146-170.

41. Driesch A.V. A Guide to the measurement of animal bones from archeological sites // Preabody Museum of Archeology and Ethnology Harvard University. Bulletin 1. 1976. P. 88-91.

42. Eisenmann V., Karchound A. Analyses multidimensionnelles des metapodes d'Equus // Bulletin Museum natn. Hist. nat. Paris: 1982. P. 75-103.

Авторлар туралы мәліметтер:

Шагирбаев Мамбет Сапарбекович - кіші ғылыми қызметкер, Ә.Х. Марғұлан атындағы Археология институты (Алматы қ., Қазақстан); mambet_87@mail.ru

Утубаев Жанболат Раимкулович - аға ғылыми қызметкер, Ә.Х. Марғұлан атындағы Археология институты (Алматы қ., Қазақстан); utubaev_z@mail.ru

\section{АРХЕОЗООЛОГИЧЕСКОЕ ИССЛЕДОВАНИЕ АСТРАГАЛОВ ЖИВОТНЫХ (по материалам городища Бабиш-мола)}

\section{М.С. Шагирбаев, Ж.Р. Утубаев}

В статье публикуются результаты археозоологического исследования астрагалов животных, найденных на городище Бабиш-мола. В ходе раскопок было найдено более 80 астрагалов. Выявлена принадлежность астрагалов к семействам следующих животных: сайге (Saiga tatarica), джейрану (Gazella subgutturosa), овце (Ovis aries), козе (Capra). Морфологические и морфометрические исследования костей выявили 
диапазон колебаний размеров у одинаковых костей (Lim), средняя арифметическая величина (М), средняя арифметическая ошибка (о). В основе результатов остеометрического исследования, астрагалы из Бабиш-молы анализировались в сравнении с астрагалами из памятников сопредельных регионов. Выявлен вариационный ряд биометрических признаков. Описан орнамент, расположенный на плантарной части астрагалов. В статье приводится 12 таблиц, в которых подробно показаны размеры астрагалов, в том числе. При проведении анализа рассмотрены особенности культов, обрядов и др., связанных с астрагалами.

Ключевые слова: археология, Жанадария, Бабиш-мола, цитадель, «Большой дом», астрагалы животных, сайга, джейран, археозоология, игры с астрагалами, культовые обряды, погребение, морфометрический анализ

\section{ARCHAEOLOGICAL STUDY \\ OF ANIMAL ASTRAGALS \\ (based on materials from the ancient settlement Babish-mola)}

\section{M.S. Shagirbayev, Zh.R. Utubayev}

The article is devoted to archaeological research of animal astragals found in the settlement of Babish-mola. During excavations in the monument, more than 80 animal astragalas were found. An archaeozoological analysis revealed that astragals belonged to the antelope family, more precisely, saig (Saiga tatarica) and gazelles (Gazella subgutturosa), as well as sheep (Ovis aries) and goats (Capra). Morphological and morphometric studies of bones revealed a range of size fluctuations for identical bones (Lim), arithmetic mean value (M), arithmetic mean error (o). Based on the results of an osteometric study, Babish-mola astragals were comparatively analyzed with the astragals of adjacent regions. A variation series of biometric features was revealed and ornaments that were superimposed on the plantar part of astragals were described. The article gives 12 tables which show all sizes of astragals in more detailed way. In the course of archeozoological research, various cult rites and games related to astragals were analyzed, using materials found in Kazakhstan as an example.

Keywords: archaeology, Zhanadaria, Babish-mola, citadel, "Big House", animal astragals, saiga, gazelles, archeozoology, games with astragals, cult rites, burial, morphometric analysis

\section{REFERENCES}

1. Akishev, A. K. 1984. Iskusstvo i mifologiya sakov (Art and mythology of Saks). Alma-Ata: "Nauka" Publ. (in Russian).

2. Alpysbayev, X. A. 1978. O nahodkah industrii kamennogo veka v Karjantau $i$ Karaoba (About finds of the Stone Age industry in Karzhantau and Karaoba). Alma-Ata: "Nauka" Publ. (in Russian).

3. Antipina, E. E., Olhovskii, V. S. 2000. In Arheologlya, paleoekologiya $l$ paleodemografiya Evrazı (Archeology, paleoecology and paleodemography of Eurasia). Moscow: "Geos" Publ., 79-88 (in Russian).

4. Artuhova, O. A. 2009. In Arhıv Instıtuta arheologii ım. A.H. Margulana (Archive A.Kh. Margulan Institute of Archeology), 2895 (in Russian).

5. Akhinjanov, S. M., Makarova, L. A., Nurumov, T. N. 1992. K istorii skotovodstva $i$ ohoty $v$ Kazahstane (po osteologicheskomu materiali iz arheologicheskih pamyatnikov eneolita $i$ bronzy) (On the history of cattle breeding and hunting in Kazakhstan (based on osteological material from archaeological sites of the Eneolithic and bronze)). Almaty: "Gylym" Publ. (in Russian).

6. Baipakov, K. M., Voyakin, D. A., Erjigitova, A. A., Savelieva, T. V., Shardenova, Z. J., Ahatov, G. A., Sherbaev, R. K. 2004. In Novye issledovaniya po arheologii Kazahstana (New research on archeology of Kazakhstan). Almaty: A.Kh. Margulan Institute of Archeology, 169-193 (in Russian). 
7. Baipakov, K. M., Savelieva, T. V., Chang, K. 2005. Srednevekovye goroda i poseleniya Severo-vostochnogo Jetysu (Medieval cities and settlements of the Northeast Jetysu). Almaty: "Credo" Publ. (in Russian).

8. Bois, M. 1987. Zoroastriitsy. Verovaniya i obychai (Zoroastrians. Beliefs and customs). Moscow: "Nauka" Publ. (in Russian).

9. Vinnikov, A. Z. 2011. In Vestnık VGU (Bulletin of Voronezh State University), 1, 87-94 (in Russian).

10. Voroshilova, S. A. 2008. In XL Mezhdunarodnaya Uralo-Povolzhskaya arheologicheskaya studencheskaya konferenciya: tezisy dokladov (XL International Ural-Volga archaeological student conference: abstracts). Samara: Samara University Publ., 157-159 (in Russian).

11. Gaiduchenko, L. L. 2011. In Tauelsizdiq kezenindegi Qazaqstan arheologiyasy: qorytyndylary men keleshegi (Archeology of Kazakhstan in independence: results and future). Almaty: A.Kh. Margulan Institute of Archeology, I, 360-365 (in Russian).

12. Gaiduchenko, L. L. 2012. In Trudy filiala Instituta arheologii im. A.H. Margulana (Proceedings of the branch of the A.Kh. Margulan Institute of Archeology), I. Astana, 160-170 (in Russian). (in Russian).

13. Grigoriev, G. V. 1948. In Sovetskaya Arheologiya (Soviet archaeology), 1, 53-68

14. Grishchuk, O. M. 2013. In Donetskii arheologicheskii sbornik (Donetsk archaeological collection), 17. Donetsk: Donetsk National University, 24-34 (in Russian).

15. Gromova, V. 1960. Opredelitel mlekopitayushchih SSSR po kostyam skeleta (Detector of mammals of the USSR on skeletal bones), 2. Moscow: USSR Academy of Sciences Publ. (in Russian).

16. Joldasbayev, S. 1975. In Arhiv Instituta istorii, arheologii i etnografii AN KazSSR (Archive of the Institute of History, Archeology and Ethnography Academy of Sciences of the Kazakh SSR), f. 11 (in Russian).

17. Zudina, V. N. 1998. Arheologicheskie drevnosti Yujnogo Srednevolgiya (Archaeological antiquities of the Southern Middle Volga region). Samara: Samara Universitu Publ. (in Russian).

18. Kovaleva, I. F. 1990. In Issledovaniya po arheologii Podneprovia (Studies on the archeology of the Dnieper). Dnepropetrovsk: Dnepropetrovsk University Publ., 59-71 (in Russian).

19. Kojomberdiev, I. 1963. In Arheologicheskie pamyatniki (Archaeological Monuments of the Talas Valley). Frunze: "Ilım" Publ., 33-79 (in Russian).

20. Kolchenko, V. A., Rott, F. G. 2007. In Materialy I issledovaniya po arheologii Kyrgyzstana (Materials and research on the archeology of Kyrgyzstan), 2. Bishkek: "Ilım" Publ., 21-34 (in Russian).

21. Kosintsev, P. A., Bachura, O. P. 2014. In Trudy filiala Instituta arheologii im. A.H. Margulana (Proceedings of the branch of the A.Kh. Margulan Institute of Archeology), 320-329 (in Russian).

22. Kurmankulov, Zh., Utubayev, Zh. R. 2019. In «edu.e-history.kz». URL: http:// edu.e-history.kz/ru/publications/view/268

23. Lipskii, A. N. 1956. In Kraevedcheskii sbornik (Local history collection), 1. Abakan: Khakass book publ., 16-24 (in Russian).

24. Lopatin, V.A. 2010. Smelovskii mogilnik (Smelov burial ground). Saratov: "Nauka" Publ. (in Russian).

25. Margulan, A. Kh., Akishev, K. A., Kadyrbayev, M. K., Orazbayev, A. M. 1966. Drevnyaya kultura Tsentralnogo Kazahstana (Ancient culture of Central Kazakhstan). Alma-Ata: "Nauka" (in Russian).

26. Maksimova, A. G., Mershchiev, M. S., Vainberg, B. I., Levina, L. M. 1968. Drevnosti Chardary (Chardara Antiquities). Alma-Ata: «Nauka» Publ. (in Russian).

27. Nurzhanov, A. A. 2014. In Margulan oqulary-2014 (Margulan readings-2014). Almaty; Pavlodar: A.Kh. Margulan Institute of archaeology, 462-472 (in Russian). 
28. Podobed, V. A., Usachuk, A. N., Tsimidanov, V. V. 2013a. In Povoljskaya arheologiya, 3 (5), 56-72 (in Russian).

29. Propp, V. Ia. 1986. Istorlcheskle kornı volshebnou skazkı (Historical roots of a fairy tale). Lenıngrad: Leningrad State University Publ. (in Russian).

30. Sotnikova, S. V. 2019. In Povoljskaya arheologiya, 1 (27), 72-84 (in Russian).

31. Sotnikova, S. V. 2014. In Vestnik arheologii, antropologi i etnografii, 2 (25), 26-34 (in Russian).

32. Sotnikova, S. V. 2015. In Vestnık Permskogo universiteta, 1 (28), 21-30 (in Russian).

33. Tolstov, S. P., Vainberg, B. I. 1967. Koikrylgan-kala pamyatnik kultury drevnego Horezma $I V$ v. do n.e. - IV v. n.e. (Koikrilgan-kala monument of the culture of ancient Khorezm $I V$ c. $B C-I V$ c. $A D$ ). Moscow: "Nauka" (in Russian).

34. Tolstov, S. P., Vorobieva, M. G., Rappoport, Yu. A. 1960. In Polevye issledovaniya Horezmskoy ekspeditsii $v 1957$ godu (Field research of the Khorezm expedition in 1957). Moscow: "Vostochnaya literature" Publ., 3-63 (in Russian).

35. Toleubayev, A. T., Jumataev, R. S., Shagirbayev, M. S. 2016. In Arheologiyadagy zertteudin zhana adisteri (New methods of archaeological research). Almaty: "Qazaq universiteti” Publ., 172-183 (in Kazakh).

36. Toleubayev, A. T., Jumataev, R. S., Shakenov, S. T., Ergabylov, A. E.., Shagirbayev, M. S. 2018. In Qazaqstan men irgeles elderdin tarihi-madeni murasyn zertteudegi zamanaui adister men turgylar (Modern methodologies and concepts in the study of the history and cultural heritage of Kazakhstan and neighboring countries). Almaty: "Qazaq universiteti” Publ., 173-178 (in Kazakh).

37. Umitqaliev, U. U. 2016. In Qazaqstannyn tarihi-madeni muralarynyn ozekti maseleleri (Actual problems of the history and cultural heritage of Kazakhstan). Almaty: "Qazaq universiteti" Publ. 111-116 (in Kazakh).

38. Tsimidanov, V. V. 2001. In Arheologicheskii almanah (Archaeological almanac), 10. Donetsk: «Lebed» Publ., 215-248 (in Russian).

39. Tsimidanov, V. V. 2015. In Teoriya i praktika arheologicheskih issledovanii (Theory and practice of archaeological research), 1 (11), 56-69 (in Russian).

40. Yudin, A. I. 2009. In Arheologiya Vostochno-Evropeiskoi stepi (Archeology of the East European steppe), 7. Saratov: "Nauchnaya kniga" Publ., 146-170 (in Russian).

41. Driesch, A. V. 1976. In Preabody Museum of Archeology and Ethnology Harvard University. Bulletin 1. Cambridge, 88-91 (in English).

42. Eisenmann, V., Karchound, A. 1982. In Bulletin Museum natn. Hist. nat. Paris. 75-103 (in English).

\section{About the Authors:}

Shagirbayev Mambet S. Junior Researcher, A.Kh. Margulan Archeology Institute, Almaty, Kazakhstan; mambet_87@mail.ru

Utubayev Zhanbolat R. Senior Researcher, A.Kh. Margulan Archeology Institute, Almaty, Kazakhstan; utubaev_z@mail.ru

\footnotetext{
Мүдделер қақтығысы туралы ақпаратты ашу. Авторлар мүдделер қақтығысының жоқтығын мәлімдейді. / Раскрытие информации о конфликте интересов. Авторы заявляют об отсутствии конфликта интересов. / Disclosure of conflict of interest information. The authors claims no conflict of interest.

Мақала туралы ақпарат / Информация о статье / Information about the article. Редакцияға түсті / Поступила в редакцию / Entered the editorial office: 04.10.2019.

Рецензенттер мақұлдаған / Одобрено рецензентами / Approved by reviewers: 11.10.2019. Жариялауға қабылданды / Принята к публикации / Accepted for publication: 18.10.2019.
} 